\title{
Yapı Denetim Kuruluşuna İmar Kanunu Kapsamında Para Cezası Verilip Verilemeyeceği Hakkında Bir İnceleme: Yapı Denetim Kuruluşlarının Fennî Mesuliyet Sorumlulukları
}

\author{
Selman Özdemir \\ Dr., Hâkim / Konya Bölge İdare Mahkemesi Üyesi, selmanozdemir3@gmail.com
}

\begin{tabular}{|c|c|}
\hline Makale Bilgileri & ÖZ \\
\hline Makale Geçmiși & \multirow{10}{*}{$\begin{array}{l}\text { İmar kolluğu kapsamında yapı denetimi işi ülkemizde mahallî düzeyde yürütülmektedir. Bu } \\
\text { kapsamda yapı denetimi ile esas olarak görevli olan idarelerin, belediyeler ve il özel idareleri } \\
\text { olduğu görülmektedir. Ancak yapı denetimi konusunda belediyeler ve il özel idareleri bazı } \\
\text { özel hukuk kişilerinden de teknik destek almaktadırlar. Yapı denetimi konusunda kamu } \\
\text { idarelerine teknik destek veren özel kişilerin başında ise yapı denetim kuruluşları ile fennî } \\
\text { mesuller gelmektedir. Bazı hallerde il özel idaresi yahut belediye encümeni tarafından, yapı } \\
\text { denetim firmalarına İmar Kanunu kapsamında para cezası verilmektedir. Yapı denetim } \\
\text { firmalarına verilen bu cezalar dava konusu edilebilmektedir. Bu cezalara ilişkin davalarda, } \\
\text { yargının önce bu firmalara imar Kanununa göre ceza verilemeyeceği görüşünü benimsediği } \\
\text { görülmüştür. Daha sonra yargının, bu görüşten dönmeye başladığ anlaşılmıştır. Bu } \\
\text { çalışmada yargının konuya ilişkin kararları tahlil edilecek; yapı denetim firmasına İmar } \\
\text { Kanununa göre idarî para cezası verilip verilemeyeceği konusu incelenecektir. }\end{array}$} \\
\hline Geliş: 25.06 .2 & \\
\hline & \\
\hline Yayın: 31.1 & \\
\hline Anahtar Kelimeler: & \\
\hline & \\
\hline & \\
\hline & \\
\hline & \\
\hline & \\
\hline
\end{tabular}

A Rewiev About Under the Construction and Zoning Law Whether to Give or Not Fined to Building Audit Establishment: Technical Application Responsibility of The Building Audit Establishments

\begin{tabular}{ll}
\hline Article Info & ABSTRACT \\
\hline $\begin{array}{l}\text { Article History } \\
\text { Received: 25.06.2020 } \\
\text { Accepted: 27.11.2020 } \\
\text { Published: 31.12.2020 }\end{array}$ & $\begin{array}{l}\text { In law enforcement in our country building inspection work is done at local level. In this } \\
\text { context, administrations charged with building inspection are municipalities and special } \\
\text { also receive technical support from some private persons on building inspections. } \\
\text { Construction supervisors and technical officers are among the primary technical supporters } \\
\text { to public administrations in the field of building supervision. In some cases, fines are issued } \\
\text { Keywords: }\end{array}$ \\
$\begin{array}{l}\text { Building inspection, } \\
\text { Technical responsible, },\end{array}$ & $\begin{array}{l}\text { inspection companies under the Zoning Code. These fines imposed on building inspection } \\
\text { firms should be the subject of litigation. In cases related to these penalties it has been } \\
\text { Administrative fine, } \\
\text { Misdemeanor, }\end{array}$ \\
$\begin{array}{l}\text { Zoning law. } \\
\text { according to the zoning law. Later, it was understood that the judiciary started to turn from } \\
\text { this view. In this study, these verdicts of the judiciary analyzed; the issue of whether an } \\
\text { administrative fine can be imposed on the building inspection company according to the }\end{array}$ \\
Zoning Law has been examined.
\end{tabular}

Atıf/Citation: Özdemir, S. "Yapı Denetim Kuruluşuna İmar Kanunu Kapsamında Para Cezası Verilip Verilemeyeceği Hakkında Bir İnceleme: Yapı Denetim Kuruluşlarının Fennî Mesuliyet Sorumlulukları", Necmettin Erbakan Üniversitesi Hukuk Fakültesi Dergisi, C. 3, S. 2, 2020, 182-207. 


\section{GİRIŞ}

Yap1 Denetimi Hakkında Kanunda, "Yap1 denetim kuruluşu: Bakanlıktan aldığı izin belgesi ile münhasıran yapı denetimi görevini yapan, ortaklarının tamamı mimar ve mühendislerden oluşan tüzel kişi”" olarak tanımlanmıştır (m.1). Bu tüzel kişilerin neredeyse tamamının limited şirket statüsünde tüzel kişilik edindikleri müşahade edilmektedir. Şirket unvanlarında ise ekseriyetle "yapı denenetimi” ibaresi yer almaktadir.

Şirket unvanında "yapı denetimi" ibaresi yer alan bu kuruluşlara bazı belediyeler tarafından, İmar Kanununun 42'nci maddesi kapsamında para cezaları verilmektedir. İmar Kanununun 42'nci maddesi kapsamında verilen para cezalarının iptali talebi ile açılan davalarda idarî yargının temyiz merciî olan Danıştay'ın uzunca bir süre “yapı denetimi kuruluşlarına İmar Kanununun 42'nci maddesine göre ceza verilemeyeceği" yönünde olduğu; temyiz merciinin bu tutumuna istinaden idarî yarg1 ilk derece mahkemelerinin ve istinaf mahakemelerinin büyük bölümünün de, İmar Kanununun 42'nci maddesinin yapı denetim kuruluşlarına uygulanmayacağından bahisle, belediye encümenleri tarafından verilen cezaların iptaline karar verdikleri gözlenmektedir. Ancak başta Danıştay olmak üzere, idarî yarg1 mahkemelerinin yavaş yavaş bu görüşten de dönmeye başladıkları da dikkati çekmektedir. Bu konuya ilişkin kararların muhteviyatına aşağıda değinilecektir.

Bu çalışmada, yapı denetim kuruluşu unvanlı şirketlere İmar Kanununa göre ceza vermenin mümkün olup olmadığı, mümkünse bunun yasal dayanağının ne olduğu hususu incelenmeye çalışılacaktır. Bu kapsamda evvelâ yapı denetiminin konusuna, yapı denetiminin kolluk niteliğine ve konuyla ilgisi bakımından yapı denetim kuruluşlarının sorumluluklarına değinilecektir. Ardından çalışmada, unvanında "yapı denetimi” yazan tüzel kişinin İmar Kanunu kapsamında görevlerinin ve sorumluluklarının olup olmadığı tartışılarak bir sonuca varılmaya çalışılacaktır. Ancak çalışma konusunun daha çok yargı kararları etrafında şekillendiğini çalışma girişinde vurgulamak uygun olacaktır. Zîra çalışma konusuna ilişkin akademik çalışmalar mevcut olmadığından, bu çalışmada tahliller mevzuat ve yargı kararları etrafında yapılarak bir sonuca varılmıştır.

Öte yandan; Yapı Denetimi Hakkında Kanunun 1/1'inci maddesinde, Yapı Denetimi Hakkında Kanun kapsamında kalmayan yapılardan bahsedilmiştir. Yapı Denetimi Hakkında Kanun kapsamında olmadığı belirtilen yapıların, yapı ruhsatı alarak inşa edilmesi zorunlu olanlarının denetimleri ve fennî mesuliyet işlemleri Yapı Denetimi Hakkında Kanuna göre değil, İmar Kanununa göre yürütülmektedir. Bu itibarla; bu çalışma kapsamındaki açıklamaların, Yapı Denetimi Hakkında Kanun kapsamında kalmayan yapıları değil, yapı denetimine tabi olan yapıları kapsamaktadır.

\section{YAPI DENETIMININ KONUSU}

Denetim, plânlanan eylem ile gerçekleşen eylemin karşılaştırılması ve bu karşılaştırma neticesinde gerçekleşen durumun plânlanan durumdan saptığının belirlenmesi halinde, bu sapmanın sebebini bulma, bu sebepleri ortadan kaldırarak plânlanan duruma ulaşılması süreci olarak açıklanabilir ${ }^{1}$. Zîra gerçekleşen olay ile gerçekleşmesi istenilen sonuçların karşılaştırılması, denetim ile mümkündür ${ }^{2}$.

Öte yandan; etkin bir yapı denetimden bahsedebilmek için, bir plânın ve planlama aracının olması şarttır ${ }^{3}$. Plâna ve plânlama aracına göre, inşa sonucu ortaya çıkan ürünün mukayese edilmesi ve denetlenmesi mümkün olabilecektir. Mevzuatta ise, bir yapının inşa edilme sürecinin denetlenmesi

1 PALA Murat / DEMIR, Mehmet Şirin, “Güneydoğu Anadolu Bölgesinde Yapı Denetimi Uygulamasında Karşılaşılan Sorunlar Ve Bu Sorunlara İlişkin Çözüm Önerileri”, Adıyaman Üniversitesi Mühendislik Bilimleri Dergisi, Y. 2017, S. 6, s.21.

$2 \quad$ PALA / DEMIR, s.21.

3 PALA / DEMIR, , s.21. 
suretiyle hem yapının proje denetiminin, hem de yapının inşasının (kendisinin) denetlenmesinin amaçlandığg belirtilmiştir.

Yapı Denetimi Hakkında Kanun hükümlerine göre, yapının projesinin denetimi ve yapının kendisinin denetimi sağlanınca "imar plânına, fen kurallarına, sanat kurallarına, sağlık kurallarına ve standartlara uygun biçimde, 'kaliteli yapı' yapılmış olacaktır” (m.1). Bu noktada "imar plânına, fen kurallarına, sanat kurallarına, sağlık kurallarına ve standartlara uygun biçimde, 'kaliteli yapı' yapmak" ile ne amaçlanmaktadır?" sorusunun cevabı, yapı denetiminin amacını daha iyi ortaya koyacaktır. Bu soruyu kanun koyucu, "can güvenliğini ve mal güvenliğini temin etmek" şeklinde cevaplamaktadır. Dolayısıyla yapı denetimi müessesesi esas olarak, can güvenliğini ve mal güvenliğini temin edecek biçimde kaliteli yapıların yapılması konusu ile ilgilenmektedir. Diğer bir deyişle, "projenin hazırlanması ve ardından başlanan inşaî faaliyet süresince" (yapı kullanma izin belgesi verilmesi sürecine kadar) imar plânına, fen kurallarına, sanat kurallarına, sağlık kurallarına ve standartlara "uygunluğun" sağlanıp sağlanmadığının denetlenmesi hususu, yapı denetiminin konusuna girmektedir.

Bu yönüyle yapı denetimi, her yapının türü ve kendi özellikleri dikkate alınarak fonksiyonellik, güvenirlilik ve ekonomiklik özelliklerini sağlamak amacı ile sistem bütünlüğü içinde yapının her parçası için projeler ve ilgili mevzuat - standart - şartname ve talimatnamelere uygunluğu; ayrıca ekonomi ve çevre değerlerini, zaman, estetik, konfor kayıplarını önlemeye yönelik laboratuvar dâhil her türlü teknik ve idarî çalışmaların, incelemelerin ve faaliyetlerin tümüdür şeklinde açıklanabilir ${ }^{4}$.

\section{YAPI DENETIMININ KOLLUK NITTELIĞí}

Ülkemizin deprem kuşağında yer alması, ülkemizde yaşayan insanları her an deprem tehlikesi ile karşı karşıya bırakmaktadır ${ }^{5}$. İnsanları deprem tehlikesinden korumak, deprem öncesinde - deprem sırasında ve deprem sonrasında gerekli önlemleri almak, bunun için kurallar koymak ve bu kuralların uygulanmasını sağlamak, devletin en önemli görevlerinden birisidir ${ }^{6}$. Nitekim 7.5 büyüklüğündeki Gölcük Depremi ve 7.2 büyülüğündeki Van Depremi, büyük çapta can ve mal kaybına neden olmuştur. Gelişmiş ülkelerde aynı büyüklükteki depremlerde ortaya çıkan kayıpların, ülkemizdeki kayıplara göre az olmasının nedenleri incelenmiş ve gelişmiş ülkelere göre ülkemizdeki yapıların kalitelerinin düşük olması ve yapıların denetimsiz şekilde imâl edilmesi, ülkemizdeki kayıpların fazla olmasının nedenlerinden en önemlisi olduğu anlaşılmıştır ${ }^{7}$.

Esasında Tanzimat döneminden itibaren başlayarak yapılara ilişkin kurallar getirildiği bilinmekle birlikte, yapı denetimine ilişkin modern kuralların Cumhuriyet dönemi ile birlikte mevzuatımızda yer almaya başladığı görülmektedir. Bu kapsamda 1930 yılında 1580 sayılı "Belediye Kanunu" ve "Umumi Hıfzıssıhha Kanunu" ile başlayan süreç, 1933 yılında "Belediye, Yapı ve Yollar Kanunu", 1944 yılında "Yer Sarsıntılarından Evvel ve Sonra Alınacak Tedbirler Hakkında Kanun" ile devam etmiş ; nihayetinde 2001 yılında Yapı Denetimi Hakkında Kanun çıkarılarak, yapı denetimi konusuna ilişkin norm süreci devam etmiştir.

\footnotetext{
$4 \quad$ KURAL, Recep / ÜNAL, Osman, “İnşaat Sektöründe Yapı Denetimi ve Afyonkarahisar İlindeki Uygulamaların Araştırılması”, Afyon Kocatepe Üniversitesi Fen ve Mühendislik Bilimleri Dergisi, Y. 2015, S. 15, s.1.

5 ÖMÜRBEK, Nuri / KARAATLI, Meltem / CÖMERT Hafize Gonca, “Ahp-Saw Ve Ahp-Electre Yöntemleri ile Yapı Denetim Firmalarının Değerlendirmesi”, Yönetim Bilimleri Dergisi, C. 14, S. 27 , Y. 2016, s. 172.

6 ÖMÜRBEK v.d., s.172.

7 DAVRAZ, Metin / BAŞPINAR, Ebru, CEYLAN, Hakan, "Yapı Denetim Kurumları Öncesi Isparta ve Yakın Civarındaki Hazır Beton Kalitesi", Teknik Bilimler Dergisi, Y. 2012, C. 2, S. 1, s.18.

$8 \quad$ ATABEY, İsmail İsa / BOZDOĞAN, Kanat Burak, "Yapı Denetim Kanunu Uygulamalarında Sivas Örneği”, Engineering Sciences, C. 7, S. 1, Y. 2012, s.120. KURAL / ÜNAL, s.1.
} 
Anayasa Mahkemesi, yapı denetiminin özünün deprem, heyelan, toprak kayması, çığ düşmesi, sel gibi tabiî afetlerden kaynaklanan yapı hasarlarının önlenmesi ve hasarların en aza indirilmesiyle birlikte; yapının varlığının, insan sağlığını ve insan hayatını güvence altına alacak şekilde sürdürülmesi, bu suretle toplum düzeninin sağlanması olduğunu belirtmektedir9. İnsanların barınarak, üreterek, çalışarak ya da sosyal ve kültürel faaliyetlerde bulunarak hayatlarının önemli bir bölümünü içinde geçirdikleri yapılarda can ve mal güvenliklerine ilişkin endișe duymadan yaşayabilmeleri, yapıların doğru projelendirilmesi ve doğru imal edilmesine, etkili bir yapı denetiminin sağlanmasına bağlıdır ${ }^{10}$.

Bu sebeple yapıların güvenli şekilde imâl edilmeleri gerekmektedir ve yapıların güvenli şekilde imâl edilmesinde, kamu yararı bulunmaktadır. Yapıların gerek tasarım, gerek imalat aşamasında insanların can ve mal güvenliğini sağlamak amacıyla denetlenmeleri gerekmekte olup ${ }^{11}$; bu yönüyle yapı denetimi süreci de başlı başına bir kolluk/zabıta faaliyetinin yürütülmesi işini ihtiva etmektedir. Zîra imar hukuku bağlamında mekâna etki eden plânlama işlemleri ile plânların zemine tatbikine dair uygulama işlemlerinin tamamı kolluk faaliyeti kapsamında kalmaktadır" ${ }^{12}$ Bu açıdan "imar hukukunun bütün işlemleri, kolluk niteliğindeki işlemlerdir" "13. Bu husus, bir imar plânının kolluk/zabıta niteliğinin mevcut olduğuna, keza bir yapı ruhsatının yahut yapı kullanma izninin de kolluk/zabıta niteliğinin mevcut olduğuna işaret etmektedir. Bu bağlamda yapı denetimi de, kolluk faaliyetleri kapsamında yürütülen işlerin bir parçasıdır.

Ancak belirtmek gerekir ki, "proje denetimi ve yapı denetimi görevi, İmar Kanununa göre (esas olarak) belediyelere ve il özel idarelerine ait bir görevdir" ${ }^{\prime 4}$. Dolayısıyla yapılardaki kolluk/zabıta, diğer bir ifadeyle denetim yetkisinin aslî sahibi, belediyeler ve il özel idareleridir.

Nitekim Anayasa Mahkemesi de, yapıların denetimi konusunda Yapı Denetimi Hakkında Kanun ile yeni ve özel bir düzenlemeye gidildiğini; yapıların denetiminin, "Devletin denetim yetkisi saklı kalmak kaydıyla", yapı denetim kuruluşu adı verilen özel hukuk tüzel kişilerine verildiğini ifade etmektedir ${ }^{15}$. Anayasa Mahkemesi'nin bu değerlendirmesi de, yapı denetiminde aslî görevin idareye ait olduğunu, yapı denetim firmalarının denetim yapmasının ilgili idarelerin denetim yetkilerini ortadan kaldırmadığını göstermektedir.

Bilindiği üzere mahallî idareler, mahallî müşterek nitelikteki ihtiyaçları karşılamak üzere kurulmuşlardır ${ }^{16}$. Mahallî idare teşkilâtlarına, bu ihtiyaçları karşılamaya yönelik görevler ve bu görevlerin îfasına yönelik yetkiler verilmiştir. Sorumluluk sahalarındaki "proje denetimi ve yapı denetimi görevi” de, belediye bakımından ve il özel idaresi bakımından mahallî müşterek ihtiyacın karşılanması görevi kapsamında kalan işlerdendir. Anayasa Mahkemesi, Yapı Denetimi Hakkında Kanun ile yapı denetim kuruluşlarına mahallî nitelikteki müşterek ihtiyaçların karşılanmasında belediyelere ve il özel idarelerine "teknik destek görevi"nin verildiğini söylemektedir ${ }^{17}$. Buna göre, yapı denetim kuruluşlarına, belediyeye ve il özel idaresine proje denetiminde ve yapı denetiminde teknik destek sağlayan şirketlerdir denilebilir. Fakat yapı denetim kuruluşlarının denetleme yetkisinin içeriğinde, tek başına kamu gücünün kullanılması ve bu bağlamda icraî bir idarî yetki kullanma hali söz konusu değildir. Zîra yapı denetim kuruluşu, projede

Anayasa Mahkemesinin 03.11.2011 tarih ve E: 2010/75, K: 2011/150 say1l kararı. Anayasa Mahkemesinin 03.11.2011 tarih ve E: 2010/75, K: 2011/150 sayll karar1. Anayasa Mahkemesinin 03.11.2011 tarih ve E: 2010/75, K: 2011/150 say1l kararı. ÖZDEMIR, Selman, "Yapı Ruhsatının Kolluk / Zabıta Niteliğı", Mahallî İdareler Dergisi, S. 51, Mart 2017, s.6.

ÖZDEMIR, Selman, İmar - İdare Hukukunda Kazanılmış Hak, Adalet Yayınları, Ankara, 2019, s.391. Anayasa Mahkemesinin 29.11.2012 tarih ve E: 2011/106, K: 2012/192 sayıl kararı. Anayasa Mahkemesinin 03.11.2011 tarih ve E: 2010/75, K: 2011/150 say1l kararı. GÖZLER, Kemal, Mahallî İdareler Hukuku, Ekin Kitabevi Yayınları, Bursa, 2018, s.72-73. Anayasa Mahkemesinin 09.11.2002 tarih ve E: 2001/377, K: 2002/59 say1l kararı. 
ve yapıda herhangi bir mevzuata aykırılığın olduğunu tespit etmesi halinde, durumu ilgili idareye bildirmekle görevli olup, kamu gücünü kullanarak icraî idarî işlemi uygulama görevi ve yetkisi, kural olarak ilgili idarede bulunmaktadır.

Anayasa Mahkemesi ilâveten, yapı denetim kuruluşlarının hizmetlerinin, diğer bir deyişle yapı denetimi kuruluşlarının proje denetimine ve yapı denetimine yönelik mahallî idarelere teknik destek verme işlerinin, devletin genel idare esaslarına göre yürütmekle yükümlü olduğu aslî ve sürekli görevler arasında bulunmadığını ifade etmiştir ${ }^{18}$. Bu bakımdan yapı denetim kuruluşlarının bir kolluk teşkilâtı ya da kolluk birimi olmadığı, ancak mahallî idarelerin imar kolluğu faaliyetinin yardımcı elemanları olarak işlev gördükleri söylenebilir.

Netice itibariyle kamu düzeni, kamu güvenliği ve kamu yararı amacıyla ihdas edilen yapı denetimi müessesesi ile yapı denetim kuruluşlarına, mahallî idarelerin yerine geçme ve onlar gibi karar alma yetkisi verilmemiş, mahallî nitelikteki müşterek ihtiyaçların karşılanması için mahallî idarelere teknik destek sağlanması işi verilmiştir ${ }^{19}$. Ayrıca, yukarıda da ifade edildiği üzere, Yapı Denetimi Hakkında Kanun ile, İmar Kanunu'nu ile düzenlenen mahallî idarelerin yapı denetim yetkileri de kaldırılmamıştır ${ }^{20}$.

\section{YAPI DENETIM KURULUŞUNUN SORUMLULUKLARI}

Bu başlık altında yapı denetim kuruluşlarının sorumluluklarının neler olduğunun tek tek sayılması yerine; konuyla olan ilgisi bağlamında, yapı denetim kuruluşlarının sorumluluk türlerine kısaca değinilerek, ardından idarî sorumluluk kapsamında yaptırım uygulanması hususu incelenmiştir.

\section{Hukukî Sorumluluk}

Yapı denetim kuruluşunun sorumluluğunu hukukî sorumluluk, cezaî sorumluluk ve idarî sorumluluk olarak üçe ayırmak mümkündür. Hukukî sorumluluğu evvela kendi içerisinde, yapı denetim kuruluşunun yapı sahibine olan hukukî sorumluluğu ve yapı denetim kuruluşunun ilgili idareye olan hukukî sorumluluğu olarak ikiye ayırmak mümkündür.

Hukukî sorumluluk, kişinin başkasına verdiği zarar sebebiyle ortaya çıkan zararın giderilmesi yükümlülüğü olarak ifade edilebilirr ${ }^{21}$. Başka bir deyişle hukukî sorumluluk, iki patrimuan arasında bozulan ekonomik dengenin yeniden kurulmasını amaçlayan, bunun yaptırım gücünü içine alan bir kurumdur ${ }^{22}$. Bir eylem neticesinde ortaya çıkan zarardan kimin sorumlu olduğunu gösteren, zarar görenin, zarar verenden zararını telafi etmesine dair talep hakkını düzenleyen normlar bütünüdürr ${ }^{23}$. Sorumluluk hukuku, "haksız fiil sorumluluğu" ve "sözleşme sorumluluğu" olarak iki türde kendisini göstermekte olup; haksız fiil sorumluluğu, objektif ve soyut hukuk kurallarının yüklediği bazı yükümlülüklerin ihlâlinden doğarken; sözleşme sorumluluğunun esasını, hukuka aykırılık değil, "borca -sözleşmeye- aykırılık" oluşturmaktadır²4. Söz konusu hukukî sorumluluk türleri ayrı ayrı ortaya çıkabileceği gibi; bir davranış hem sözleşmeye aykırılık oluşturabilir hem de haksız fiil niteliğinde olabilir ${ }^{25}$.

Anayasa Mahkemesinin 03.11.2011 tarih ve E: 2010/75, K: 2011/150 say1l karar1. Anayasa Mahkemesinin 09.11.2002 tarih ve E: 2001/377, K: 2002/59 say1l karar1. Anayasa Mahkemesinin 09.11.2002 tarih ve E: 2001/377, K: 2002/59 say1l karar1. ÖZEN, Mustafa, “İş Kazalarında Hukuki, Cezai ve İdari Sorumluluk”, Ankara Barosu Dergisi, Y. 2015, S. 2, s.189.

ESİN, Yüksel, İdarenin Hukukî Sorumluluğu, Balkanoğlu Matbaacılık, Ankara, 1973, s.14.

ÖZEN, s.189.

DEMIRCIOĞLU, Huriye Reyhan, "Sorumluluk Hukukunun İkili Yapısının Aşılması Çabalarının Ürünleri Olarak Culpa In Contrahendo Ve Güven Sorumlulukları”, Sorumluk ve Tazminat Hukuku Sempozyumu2009, Gazi Üniversitesi Hukuk Fakültesi Yayınları, Ankara, 2009, s.219.

25 REİSOĞLU, Safa, Borçlar Hukuku - Genel Hükümler, Beta Yayınları, İstanbul, 2004, s.333.
} 
Yapı denetim kuruluşunun yapı sahibi ile olan ilişkisine bakıldığında, bu süreçte yapı sahiplerinin; yapının ruhsat ve eklerine, fen kurallarına, sanat kurallarına ve sağlık kurallarına aykırı, eksik, hatalı ve kusurlu yapılmış olmasına karşı korundukları gözlenmektedir. Bu kapsamda denetimi yapan yapı denetim kuruluşlarına, görevlerini gereklerine uygun şekilde yapmalarına yönelik sorumluluklar yüklenmiştir ${ }^{26}$. Her şeyden evvel yap1 denetim hizmeti; yapı denetim kuruluşu ile yapı sahibi arasında akdedilen hizmet sözleşmesi hükümlerine göre yürütülmektedir. Bu sözleşmede; taahhüt edilen hizmetin konusu, hizmetin yeri, inşaat alanı, inşa süresi, varsa yapı sahibi ile yapı müteahhidi arasında akdedilen sözleşmede yer alan yapının fizikî özellikleri, yapı denetimi hizmet bedeli, yapı denetiminde görev alacak teknik personelin listesi ve tarafların diğer yükümlülükleri yer almaktadır. Bu açıdan yapı denetim kuruluşunun sözleşme ilişkisi dolayısıyla ve denetim esnasındaki haksız fiil niteliğindeki davranışlarının sonuçları dolayısıyla yapı sahibine karşı hukukî sorumluluğu bulunmaktadır.

Ayrıca yapı denetim kuruluşunun ilgili idareye karşı hukukî sorumluluğu da bulunmaktadır. Yapı denetimine ilişkin süreçte aslî görevin ilgili idarelerde olması nedeniyle, yapı denetiminin gereği gibi îfa edilmemesi sebebiyle "hizmet kusuruna dayanarak" ilgili idareler aleyhine açılacak olan tam yargı davaları sonucunda, ilgili idarelerin (belediyenin veya il özel idaresinin) bir tazminat ödemesi durumunda, ilgili idarenin yapı denetim kuruluşuna ödediği tazminatı rücû etmesi mümkündür. Bu husus da yapı denetim kuruluşunun hukukî sorumluluğu kapsamında kalan bir konudur.

Öte yandan; yapı denetim kuruluşunun bir de kanundan kaynaklanan hukukî sorumluluğu bulunmaktadır. Yapı alanında, yapı işleri kapsamında kazı, yarma, doldurma, hafriyat, inşaat, montaj, tadilat, söküm, boyama, restorasyon, tamir, yıkım, elektrik, doğrama gibi çeşitli sanat, inşaat ve mühendislik işleri yürütülmektedir ${ }^{27}$. Bu işlerin yürütülmesi esnasında çalışanın düşmesi, çalışanın üzerine malzeme düşmesi, elektrik çarpması, yapı makinesi kazaları, çökme ve göçüğe bağlı kazalar, şantiye içi trafik kazaları, patlayıcı madde kullanımına bağlı kazalar, montaj vd işlere bağlı kazalar dolayısıyla pek çok ölüm ve yaralanma olayları ortaya çıkabilmektedir ${ }^{28}$. Yapı denetim sisteminin, inşaî faaliyet esnasında iş sağlığ ve güvenliği konusunda tespit edilecek eksikliklerin giderilmesini temin bakımından da bir takım ödevleri bulunmaktadır ${ }^{29}$. İş sağlığı ve güvenliği noktasında gereken denetim, uyarı ve bildirim ödevlerinin objektif olarak, usûlünce yerine getirilmemesi halinde, yapı denetim kuruluşunun meydana gelecek zarar verici olaydan ötürü sorumluluğu ortaya çıkacaktır ki; bu durum da yapı denetim kuruluşunun kanundan kaynaklı olan hukukî sorumluluğu kapsamında kalmaktadır ${ }^{30}$.

\section{Cezaî Sorumluluk}

Yapı denetim kuruluşlarının bir diğer sorumluluğu ise, cezaî sorumluluktur. Burada kastedilen cezaî sorumluluk, Türk Ceza Kanununa ilişkin cezaî sorumluluktur. Yapı Denetimi Hakkında Kanunda kuruluşun ortakları, yöneticileri, mimarları ve mühendisleri, yapı müteahhidi, şantiye şefi, proje müellifi gerçek kişiler ile laboratuvar görevlileri, görevi kötüye kullanma suç isnadının sübuta ermesi halinde, hapis cezası ile cezalandırılacaklardır ${ }^{31}$. Esas çalışma konusu cezaî sorumluluk olmadığından, bu sorumluluk türüne ilişkin detaylı açıklama yapılması yerinde görülmemiştir.

\footnotetext{
26 Anayasa Mahkemesinin 21.01.2010 tarih ve E: 2008/94, K: 2010/13 sayılı karar1.

27 DUMAN, Barış, “4708 Sayılı Kanun Çerçevesinde Yapı Denetim Kuruluşunun İş Sağlığı ve Güvenliği

Sorumluluğu”, Türkiye Barolar Birliği Dergisi, Y. 2019, S. 143, s.285.

Duman, s.286.

Duman, s.287.

Duman, s.299 vd.

KIRANER, Cihan, "Yapı Denetimi Kuruluşları ve Türkiye'de Yapı Denetimi Uygulamaları", http://www.leventbicakci.com/cihan.pdf, s.8, erişim tarihi 18.06.2020.
} 


\section{İdarî Sorumluluk}

Hukukî sorumluluğun haricinde, yapı denetim kuruluşlarının idareye karşı sorumluluk olarak ifade edilebilecek, idare hukukuna ve kabahatler hukukuna müteallik sorumlulukları da bulunmaktadır. Bu sorumluluğun "fennî mesuliyet" sorumluluğu olarak ifade edilmesi mümkündür ${ }^{32}$.

Yapı denetim kuruluşunun idareye karşı sorumlulukları, daha çok bu kuruluşların ilgili idarelere yönelik üstlendikleri görevlerle ilgilidir ${ }^{33}$. Yapı denetim kuruluşunun idareye karşı sorumluluklarının (esas olarak) iki kanuna dayalı olduğu görülmektedir. Bu bağlamda yapı denetim kuruluşlarının idareye karşı sorumluluklarını Yapı Denetimi Hakkında Kanuna göre sorumluluk ve İmar Kanununa göre sorumluluk olarak iki başlık altında ele almak mümkündür.

Yapı Denetimi Hakkında Kanunda ve bu Kanun ile ilgili olan mevzuatta öngörülen esaslara göre denetim görevini yerine getirmedikleri tespit edilen yapı denetim kuruluşlarına, Yapı Denetimi Hakkında Kanunun 8 'inci maddesinde yer verilen idarî yaptırımlar uygulanacaktır. Yapı Denetimi Hakkında Kanunda idarî yaptırımların, "yapı denetim kuruluşu tüzel kişiliğine yönelik idarî yaptırımlar" ve yapı denetim şirketinde çalışan "gerçek kişi teknik personele yönelik idarî yaptırımlar" olarak iki şekilde kurgulandığı görülmektedir. Yapı denetim kuruluşu tüzel kişiliğine yönelik idarî yaptırımları ise; i) Para cezası, ii) Bir yıl yeni iş almaktan men cezası, iii) İzin belgesinin iptal edilerek faaliyete son verme yaptırımı şeklinde özetlenebilir.

Yap1 denetim kuruluşunun idareye karşı sorumluluğunun bir diğer yasal dayanağ1 ise, İmar Kanunu'dur. İmar Kanununun 42'nci maddesine göre, tüzel kişi şirkete para cezası verilmektedir. Bu çalışmanın ana konusu, yapı denetim kuruluşunun idareye karşı İmar Kanunu kapsamındaki sorumluluğu ve sorumluluğu yerine getirmemenin müeyyidesidir. Diğer bir ifadeyle İmar Kanunu kapsamında yap1 denetim kuruluşlarına ceza verilip verilemeyeceği bu çalışmada incelenmektedir.

\section{YAPI DENETIM ŞIRKETINE IMMAR KANUNUNUN 42'NCI MADDESİ KAPSAMINDA IDARÎ PARA CEZASI VERILIP VERILEMEYECEĞININ İNCELENMESİ}

\section{İlgili Yargı Kararlarının Özeti}

$\mathrm{Bu}$ başlık altında, ülkedeki her bir mahkemede ne tür kararlar verildiği incelenmeyecektir. Zaten çalışmanın konusu da bu değildir. Bu başlık altında, yapı denetim kuruluşlarına İmar Kanununa göre para cezası verilebilecek midir? Verilemeyecek midir? Konusunda yargı tarafından ortaya konan iki ana görüşe değinilecektir. Bu görüşlerden ilki, yapı denetim kuruluşlarına İmar Kanununa göre ceza verilemeyeceği noktasında toplanmakta iken, görüşlerden diğeri de ceza verilebileceği noktasında toplanmaktadır.

Konuyla ilgili yargı kararlarına bakıldığında, yargı kararlarının başlangıçta yapı denetim kuruluşlarına hangi sıfatla olursa olsun, İmar Kanununa göre ceza verilemeyeceği yönünde iken, bu makalenin kaleme alınmaya başladığı tarihten sonra bu görüşün değiştiği ve yapı denetim kuruluşuna İmar Kanununa göre ceza verilebileceğinin kabul edildiği anlaşılmaktadır.

32 AKBIYIKLI, Rıfat / OPÇiN, Gülhan / AKDEMIR, Merve / GÜNDÜZ, Emre, "Türkiye'de Yapı Denetim Kavramı, Amacı, Yasal Dayanağı ve Uygulamaları Üzerine Bir İnceleme", Uluslararası Katılımlı 7. İnşaat Yönetimi Kongresi Bildiriler Kitabı, TMMOB İnşaat Mühendisleri Odası Samsun Şubesi Yayınları, Samsun, 2017, s.222.

33 AKAT, Ali, “4708 Sayılı Yapı Denetimi Hakkında Kanun Ve İlgili Mevzuatında; Kontrol Elemanı İnşaat Mühendislerinin Görev Ve Sorumlulukları", Yapı Denetimi Bilgilendirme Sunumu, TMMOB İnşaat Mühendisleri Odası İzmir Şubesi, İzmir, 2016, s.3 vd., http://www.imo.org.tr/resimler/dosya_ekler/42beb6074c14528_ek.pdf?tipi=2\&turu=X\&sube=16, erişim tarihi 18.06.2020. 
Yapı denetim kuruluşlarına İmar Kanununa göre ceza verilemeyeceği görüşü esas olarak, "bir yapı denetim şirketinin görev ve sorumlulukları ile uygulanacak idarî yaptırımların Yapı Denetimi Hakkında Kanunda düzenlendiği, (yapı denetim kuruluşlarının) İmar Kanununda düzenlenen fennî mesullük yetkilerinin ve sorumluluğunun bulunmadı̆̆̆, dolayısılla söz konusu inşaatın ruhsat ve eklerine aykırı yapılmasından yapı denetim kuruluşunun fennî mesul olarak sorumlu tutulamayacağını; bu nedenle yapının ruhsat ve eklerine aykırı yapıldı̆̆ından bahisle yapı denetim kuruluşuna fennî mesul sıfatı ile İmar Kanununun 42 'nci maddesi kapsamında para cezası verilmesinin hukuka aykırı olduğu" düşüncesine dayanmaktadir ${ }^{34}$.

Danıştay da, "fennî mesullerin denetimi olmaksızın inşaat ve tesisatlara ilişskin yapım işlerinin sürdürülemeyeceği yolundaki İmar Kanununun 28'inci maddesi ile yapı denetim kuruluşlarının sorumluluğunu düzenleyen Yapı Denetimi Hakkında Kanun maddeleri birlikte incelendiğinde; yapı denetim şirketinin görev ve sorumluluklart ile uygulanacak idarî yaptırımların Yapı Denetimi Hakkında Kanun maddelerinde düzenlendiği, uyuşmazlık konusu inşaatın ruhsat ve eklerine aykırı yapılmasından dolayı yapı denetim kuruluşunun İmar Kanunu kapsamında para cezasıyla cezalandırılamayacă̆ı; yapı denetim şirketine Imar Kanununun 42 'nci maddesi uyarınca para cezast verilmesine ve cezanin tahsili amacıyla tesis edilen işlemde hukuka uygunluk bulunmadığı" görüşündedir ${ }^{35}$. Danıştay'ın bu görüşünü 4 Kasım 2019 tarihine kadar sürdürdüğ̈̈; nitekim konuya ilişkin olan ve yukarıdaki görüş doğrultusunda verilen son karar olan 4 Kasım 2019 tarihli kararda da, yukarıdaki gerekçelere yer verildiği görülmüştür ${ }^{36}$.

Yaptığımız incelemede, Danıştay’ın 28 Kasım 2019 tarihinden itibaren görüş değiştirdiği gözlenmektedir. Bu tarihten itibaren verdiği kararlarda, yapı denetim kuruluşuna İmar Kanununa göre para cezası verilebileceği yönünde kararlar verdiği görülmektedir ${ }^{37}$. Danıştay'ın bu yöndeki kararları ise, "yapı denetim kuruluşlarının fennî mesul hükümlerine tabi olduğu" düşünesine dayanmaktadır.

\section{Durumun Değerlendirilmesi}

Yapı denetim kuruluşuna İmar Kanunu kapsamında para cezası verilip verilemeyeceğinin açıklığa kavuşturulabilmesi için, yapı denetim kuruluşuna İmar Kanununa ilişkin bir görev ve sorumluluk verilip verilmediğinin incelenmesi gerekmektedir. Esasında İmar Kanununda, yapı denetim kuruluşuna ceza verileceğine yönelik bir hüküm bulunmamaktadır. Belediye ve il özel idaresi encümenleri de, yapı denetim kuruluşu sıfatlarına istinaden bu şirketlere para cezası vermemektedirler. İmar Kanununda, fennî mesullerin sorumlulukları ile fennî mesullere para cezası verilmesine ilişkin hükümlere yer verilmiştir. Belediye (ve il özel idaresi) encümenleri de fennî mesuliyet görevinin mevzuata uygun yerine getirilmemesi nedeniyle yapı denetim kuruluşlarına ceza vermektedirler.

$\mathrm{Bu}$ bağlamda, yapı denetim unvanlı bir şirkete İmar Kanunu kapsamında para cezası verilip verilmeyeceğinin açıklığa kavuşturulabilmesi için;

i) Evvelâ yapı denetim kuruluşlarının fennî mesullük görevlerinin olup olmadığının ele alınması,

ii) Sonra yapı denetim kuruluşunun fennî mesullük görevinin mevcut olduğuna kanî olunursa, yap1 denetim kuruluşunun hangi mevzuat/mevzuatlar kapsamında fennî mesuliyet görevlerinin ve sorumluluklarının bulunduğunun incelenmesi,

\footnotetext{
34 Konya Bölge İdare Mahkemesi 2’nci İdarî Dava Dairesinin 09.05.2019 tarih ve E: 2018/1786, K: $2019 / 999$ say1l karar1.

35 Danıştay 6 ncı Dairesinin 15.10.2019 tarih ve E: 2019/7029, K: 2019/9400 sayılı kararı.

36 Danıştay 6 ncı Dairesinin 04.11.2019 tarih ve E: 2019/5807, K: 2019/10218 sayılı kararı.

37 Danıştay 6 ncı Dairesinin 28.11.2019 tarih ve E: 2019/20126, K: 2019/12558 sayılı kararı.

Danıştay 6 ncı Dairesinin 24.12.2019 tarih ve E: 2019/5398, K: 2019/14931 sayılı kararı.
} 
iii) Arından, fennî mesuliyet sebebiyle yapı denetim kuruluşuna İmar Kanunu kapsamında ceza uygulanıp uygulanamayacağının tartışılması icab etmektedir.

\section{Fennî Mesuliyet Kavramı}

Fen kelimesi, “fenn” kelimesinin günümüz Türkçesine dönüşmüş halidir. "Fenn” (نف) kelimesi bilim, teknik, ilim, hüner, sanat manâlarına gelmektedir ${ }^{38}$. "Fennî mesuliyet" tamlamasında kullanılan "Fennî" (ى) kelimesi ise fen ile ilgili olan, bilimsel yöntemlere ve tekniğe uygun biçimde yapılan anlamlarına gelmektedir ${ }^{39}$. Yine "fennî mesuliyet" tamlamasında yer alan ve günümüzde "mesuliyet" olarak ifade edilen kelime ise aslında "mesuliyyet” şeklinde kullanılan bir kelimedir. Mesuliyyet (تيلو ئسم) kelimesi de sorumlu olma, sorumluluk anlamına gelmektedir ${ }^{40}$. Kelime mânalarından yola çıkıldığında "fennî mesuliyet" kavramının bir işin teknik yönünden sorumlu olma, işin bilime - sanat kuralarına - teknik kurallara uygun olup olmamasından mesul olma halini ifade ettiği söylenebilir.

Mevzû anlamda ise, bir inşaatın bilime - sanat kurallarına ve teknik kurallara uygun olup olmadığına ilişkin sorumluluğa, "fennî mesuliyet" adı verilmektedir. Planlı Alanlar İmar Yönetmeliğinde ${ }^{41}$ "Fennî mesul: Yapının tüm malzemeleri ve tesisatı ile birlikte plâna, ruhsata, ruhsat eki etüt ve projelere, standartlara, teknik şartnâmelere uygun olarak inşa edilmesinin kamu adına denetimini üstlenen, ruhsat eki etüt ve projelerin gerektirdiği uzmanlığı haiz meslek mensupları" olarak tanımlanmıştır (m.4/aa).

İmar Kanununda ise, "Fennî mesul mimarlar ve mühendisler uzmanlık alanlarına göre; yapının, tesisatı ve malzemeleri ile birlikte bu Kanuna, ilgili diğer mevzuata, uygulama imar plânına, ruhsata, ruhsat eki etüt ve projelere, standartlara ve teknik şartnamelere uygun olarak inşa edilmesini denetlemekle görevlidir" hükmüne yer verilmiştir (m.26/1).

İmar Kanunundaki ve Planlı Alanlar İmar Yönetmeliğindeki bu hükümlerden fennî mesuliyeti; "mimarî fennî mesuliyet", "statik fennî mesuliyet" ve "tesisat fennî mesuliyet" olarak sinıflandırmak mümkündür. Buna göre yapının fennî mesuliyeti konusu, ilgisi ve yapım aşamasına göre mimar, inşaat mühendisi, makina mühendisi ve elektrik mühendisi tarafından ayrı ayrı yürütülmektedir. Fakat ilgili idare, yapıya ilişkin olarak mimarî proje - statik proje ve tesisat proje haricinde başka ek projeler bulunmakta ise, bu ek proje hangi meslek alanını ilgilendirmekte ise, bu meslek alanından Yönetmelikte "meslek adamı" diye tabir edilen kişilerin ek projelerin fennî mesuliyetini istemesi zorunludur.

Fennî mesuller, teknik uygulama sorumlusu olarak iş alan serbest mimarları ve serbest mühendisleri ifade etmektedir ${ }^{42}$. İmar Kanununda yapım ve denetim ayrı sorumluluklar olarak düzenlenmiş olup; fennî mesul, yapım işlerinin teknik denetiminden sorumlu olanları kapsamına almaktadır ${ }^{43}$.

Fennî mesullerin, inşaatın başlamasından inşaatın tamamlanması sonrasında, yapı kullanma izin belgesi aşamasına kadar, hatta yapı kullanma izin belgesine ilişkin olarak sorumlulukları bulunmaktadır.

38 KANAR, Mehmet, Osmanlı Türkçesi Sözlüğü, Say Yayınları, İstanbul, 2009.

DEVELLİOĞLU, Ferit, Osmanlıca-Türkçe Ansiklopedik Lûgat, Aydın Kitabevi Yayınları, Ankara, 2007, s.256.

39 DEVELLİĞLU, s.256. Türk Dil Kurumu, "Fennî”, https://sozluk.gov.trl, erişim tarihi 13.02.2020.

$40 \quad$ KANAR, s.301.

$41 \quad$ 03.07.2017 tarih ve 30113 sayılı Resmî Gazetede yayımlanmıştır.

42 ATABEY, İsmail İsa / BOZDOĞAN, Kanat Burak, "Yapı Denetim Kanunu Uygulamalarında Sivas Örneği”, 6. İnşaat Yönetimi Kongresi Kitabı, TMMOB İnşaat Mühendisleri Odası Yayınları, Bursa, 2011, s.308.

43 MEYDANLI ATALAY, Hilâl / ENGIN, Serkan, "Yapı Denetiminin İstihdama Katkısı", TMMOB İnşaat Mühendisleri Odası 3. Yapı Denetimi Sempozyumu, 5-6 Ekim 2013 Diyarbakır Sempozyum Kitabı, İnşaat Mühendisleri Odası Yayınları, Ankara, 2013, s.332. 
Fennî mesullerin yapı kullanma izin belgesini imzalamak zorunda olmalarının altında ise, bütün yapım aşamalarını imar planına uygunluktan başlayarak fennî mesulün son olarak bir kez daha incelemesi, varsa yanlışları tespit etmesi ve varsa hatalı imalâtla ilgili imar mevzuatı kurallarının uygulanmasını (yapı kullanılmaya başlanmadan evvel) sağlanmasını temin etme görevi yer almaktadır ${ }^{44}$.

Fennî mesuliyeti üzerine alan fen adamı; kamuya karşı sorumludur ${ }^{45}$. Zîra denetimi kamu adına yapmaktadır. Bu sebeple, kamuya karşı sorumluluğa ilişkin ceza normları öngörülmüştür. Fennî mesul aynı zamanda ilgili idareye (belediyeye) karşı da sorumludur. Bu sorumluluklarını yerine getirmek maksadıyla yine ceza normları öngörülmüştür. Ve nihayet fennî mesul yapı sahibine karşı, hem sözleşme hem de kanun ve yönetmelik gereği sorumludur.

\section{Yapı Denetimi Kuruluşunun İdareye Karşı Fennî Mesul Sıfatının Olup Olmadığı Konusu}

Yap1 denetimi kuruluşunun idareye karşı fennî mesullük görevinin olup olmadığını açıklığa kavuşturabilmek için, Yapı Denetimi Hakkında Kanunun neden çıkarıldığg konusunu kısaca ele almak, ayrıca mevzuatta yapı denetim kuruluşuna fennî mesul sorumluluğunun (da) tevdi edilip edilmediğini sorgulamak gerekmektedir.

Yapı Denetimi Hakkında Kanunun genel gerekçesinde, "Ülkemizde yerleşme ve yapılaşmalara, İmar Kanunu ve ilgili yönetmelik hükümleri ile getirilen denetime ilgili idarelerce uyulmadığ araştırmalarda, proje denetimi aşamasında dahi projelerin \% 91 'inde tasarım, hesap ve çizim hatalarının olduğu, uygulamanın ise hiç denetlenmediği, şantiyelerin \% 90'ında yönetmelik ve standartlara aykırı beton döküldüğ̈̈, beton mukavemet değerlerinin projelerde öngörülenden ortalama \% 40 daha az olduğu tespit edilmiştir" tespitlerine yer verilmiştir ${ }^{46}$.

$\mathrm{Bu}$ tespitlerin ardından genel gerekçe içinde, "araştırmalar ve yaşanan son depremler, Imar Kanununda yapım işlerinde rol alan teknik uygulama sorumlusunun (fennî mesulün), yapı projelerini ve uygulamaların denetlemekle sorumlu olan belediyelerin ve valiliklerin, uygulamayı hiç denetleyemediklerini bütün çıplaklığı ile ortaya koymuştur" açıklamasına yer verilmiştir ${ }^{47}$.

Ardından, "Ülkemizdeki yapı denetim sistemi ve yapım aşamasında görev alan fennî mesullerin sorumluluklarını yeniden düzenlemek ve kâğıt üzerinde denetlenmiş gibi görülen, ancak hemen hemen hiç denetlenmeyen yapıların teknik uygulama sorumlusu fennî mesullere verilecek cezalar ile ilgili yeni bir kanunî düzenleme getirmek zorunlu olmuştur" değerlendirmelerine yer verilmiştir ${ }^{48}$. Nitekim konuya ilişkin bir panelde konuşmac1, "Birebir konuştuğum fennî mesullere inşaatın nerede olduğunu sorduğumda cevap veremediklerini gördüm" beyanında bulunarak ${ }^{49}$, inşaatın nerede olduğunu dahi bilmeden, inşaatı görmeden, kâğıt üzerinde inşaatların denetiminin yapıldığını çarpıcı biçimde ifade etmiştir.

\footnotetext{
44 DİNÇ, Güney, "Depremler, Mimar - Mühendisler ve Hukuk", http://www.guneydinc.com/makaleler/122.pdf, erişim tarihi 11.01.2020.

45 ARTUKMAÇ, Sadık, Türk İmar Hukuku, Ayyıldız Matbaası, Ankara, 1969, s.232.

46 TBMM, Başbakanlık Kanunlar ve Kararlar Genel Müdürlüğ̈̈’nün 22.01.2001 Tarih ve 3065 Sayılı Yazıs1 Eki "Yapı Denetimi Hakkında Kanun Tasarısı ve Tasarı Gerekçesi", s.1, https://www.tbmm.gov.tr/tutanaklar/TUTANAK/TBMM/d21/c068/tbmm21068128ss0732.pdf, 10.01.2020. Başbakanlık Kanunlar ve Kararlar Genel Müdürlüğü'nün 22.01.2001 Tarih ve 3065 Sayılı Yazısı Eki "Yapı Denetimi Hakkında Kanun Tasarısı ve Tasarı Gerekçesi”, s.2. Denetimi Hakkında Kanun Tasarısı ve Tasarı Gerekçesi”, s.2.

49 ÇELIK, Mehmet, "Yapı Denetim Mevzuatı Ve Uygulamada Karşılaşılan Sorunlar - Tartışmalar Kısmı”, V. Ulusal Tesisat Mühendisliği Kongresi Ve Sergisi Paneller Kitabı, TMMOB Makine Mühendisler Odası Yayınları, İzmir, 2001, s.20.
} 
Kanunun gerekçesinden de anlaşılacağı üzere kanun koyucu, belediyelerin ve il özel idarelerinin proje ve yapı denetimine ilişkin görevlerini ihmal ettikleri tespitini yapmıştır. Belediyeler ve il özel idareleri yapı denetimine ilişkin görevlerini yapmadıkları gibi, belediyelerin ve il özel idarelerinin rehavetinden etkilenerek fennî mesullerin de yapı denetimine ilişkin görevlerini yerine getirmedikleri görülmüştür. Bu nedenle kanun koyucu tarafından görevlerini ihmal eden belediyelere, il özel idarelerine ve fennî mesullere görevlerini ihmal ettirmemeyi sağlayan mekanizmaları uygulamak (örneğin adlî ve idarî soruşturmalar yapıp müeyyideler uygulamak) yerine, proje ve yapı denetimi işini başka bir müessese ihdas ederek çözülmeye çalışılmıştır. Bu müessesenin ihdasının, proje ve yapı denetimi sorunlarını çözüp çözmediği ise tartışmalıdır ${ }^{50}$.

Yapı Denetimi Hakkında Kanunun 2'nci maddesinin gerekçesinde, “yapı denetim kuruluşları(nın) imar mevzuatında yer alan fennî mesulün yerine ikame edildiği”" belirtilmiştir ${ }^{51}$. Yapı Denetimi Hakkında Kanunun genel gerekçesinde ve madde gerekçesinde yer alan yukarıdaki açıklamalardan yola çıkarak yargının, İmar Kanununda yer alan fennî mesullere ilişkin cezaların yapı denetim kuruluşlarına uygulanamayacağı yönündeki kararları verdiği anlaşılmaktadır. Zîra genel gerekçedeki açıklamalara göre, Yapı Denetimi Hakkında Kanun fennî mesullerin sorumluluklarını ve bunlara verilecek cezalarla ilgili yeni bir sistem getirmiştir. Anayasa Mahkemesi de, genel gerekçedeki ve madde gerekçesindeki yukarıdaki değerlendirmelerden yola çıkarak, "(Yapı Denetimi Hakkında Kanun'la) İmar Kanununda yer alan fennî mesul müessesesinin yerine tüzel kişiliğe sahip “yapı denetim kuruluşları”nın ikame edildiğị”ni söylemektedir ${ }^{52}$.

Yap1 Denetimi Hakkında Kanunun gerekçesindeki açıklamalardan ve Anayasa Mahkemesi’nin değerlendirmesinden, İmar Kanunundaki fennî mesullük müessesesi yerine yapı denetimi müessesesinin getirildiği; bu duruma istinaden yargının da "yapı denetim kuruluşlarına İmar Kanunundaki fennî mesuller içi öngörülen cezaî hükümlerin değil, Yapı Denetimi Hakkında Kanununda yapı denetim kuruluşları için öngörülen cezaî hükümlerin uygulanması gerektiği” yorumunu yaptığı anlaşılmaktadır. Ancak Yap1 Denetimi Hakkında Kanunun, imar mevzuatındaki fennî mesuliyet kurumunu tamamen ilga etmediği açıktır. Çünkü Yapı Denetimi Hakkında Kanunun 3/1'inci maddesinde, "Bu Kanunun uygulanmasında, yapı denetim kuruluşları imar mevzuatı uyarınca öngörülen fennî mesuliyeti ilgili idareye karşı üstlenir" hükmü yer almaktadır.

Görüldügüü üzere Yapı Denetimi Hakkında Kanun, yapı denetim kuruluşlarına bir sorumluluk (daha) yüklemektedir. Bu sorumluluk, yapı denetim kuruluşunun aynı zamanda imar mevzuatındaki fennî mesuliyeti üstlenme sorumluluğudur. Dolayısıyla yapı denetimi ile ilgili özel mevzuat olan Yapı Denetimi Hakkında Kanun, yapı denetim kuruluşlarına;

a) Hem Yapı Denetim Kanunu kapsamında yapı denetim görevi ve bu göreve ilişkin sorumluluğu,

b) Hem de İmar Kanunu kapsamında fennî mesuliyet görevi ve bu göreve ilişkin sorumluluğu vermiştir.

Yapı denetim kuruluşunun aynı zamanda idareye (belediyeye veya il özel idaresine) karşı imar mevzuatında öngörülen fennî mesuliyeti üstlendiğine ilişkin Kanun maddesinin gerekçesinde de, "Madde ile, yapı denetim kuruluşlarının yapı sahibi ile ilgili idareye karşı sorumlulukları, sorumluluğun kapsamı

\footnotetext{
50 Konuya ilişkin muhtelif değerlendirmeler için Bkz.: BAYRAM, Savaş / AYDINLI, Serkan / BUDAK, Abdülkadir / ORAL, Emel, "Türkiye'de Yapı Üretiminde Ve Denetiminde Yaşanan Etik Sorunlar", Pamukkale Üniversitesi Mühendislik Bilimleri Dergisi, C. 24, S. 3, Y. 2018, s.461-467.

51 Başbakanlık Kanunlar ve Kararlar Genel Müdürlüğü’nün 22.01.2001 Tarih ve 3065 Sayılı Yazısı Eki "Yap1 Denetimi Hakkında Kanun Tasarısı ve Tasarı Gerekçesi”, s.2.

52 Anayasa Mahkemesinin 26.02.2002 tarih ve E: 2001/377, K: 2002/59 say1l karar1.
} 
ile sorumlu olacakları durumların düzenlendiği" açıklamasına yer verilmiştir ${ }^{53}$. Madde metni ve madde gerekçesinde yer alan açıklama birlikte değerlendirildiğinde; yapı denetimi işini üstlenen şirketin, aynı zamanda inşaatın fennî mesuliyet görevini (de) üstlendiği anlaşılmaktadır. Bu husus da, hukukî statü olarak yapı denetimi kuruluşunun;

i) Hem yapı denetçisi hukukî statüsüne tabi olduğunu,

ii) Hem de fennî mesul hukukî statüsüne tabi olduğunu göstermektedir ${ }^{54}$. Bu duruma istinaden, yap1 denetimi ile ilgili özel mevzuat olan Yapı Denetimi Hakkında Kanunun, yapı denetim kuruluşlarına "hem Yap1 Denetimi Hakkında Kanun kapsamında yapı denetim görevi”, "hem de İmar Kanunu kapsamında fennî mesuliyet görevi” tevdi ettiği anlaşılmaktadır. Söz konusu görevler dolayısıyla,

1) Yapı Denetimi Hakkında Kanun ve ikincil mevzuatı kapsamındaki görev ve sorumlulukları bakımından yapı denetim kuruluşunun "yapı denetçisi sıfatı ile" Yapı Denetimi Hakkında Kanun'a tabi olduğu,

2) İmar Kanunu ve ikincil mevzuatı kapsamındaki görev ve sorumlulukları bakımından yapı denetim kuruluşunun "fennî mesul sıfatı ile” İmar Kanununa tabi olduğu sonucuna varılmaktadır.

Bu bakımdan; bir yapı denetimi kuruluşunun, yapı denetimi görevi ve sorumluluğu yanında, aynı zamanda idareye (belediyeye veya il özel idaresine) karşı imar mevzuatında öngörülen fennî mesullük görevinin ve sorumluluğunun da bulunduğu, fennî mesuliyet görevi bakımından yapı denetimi kuruluşunun İmar Kanunu hükümlerine tabi olduğu sonucuna varılmaktadır.

Yapı Denetim Kuruluşuna "Fennî Mesuliyet Görevi Nedeniyle” İmar Kanunu Kapsamında Ceza Uygulanıp Uygulanamayacağının İncelenmesi

Yap1 denetim kuruluşunun idareye (belediyeye veya il özel idaresine) karşı imar mevzuatında öngörülen fennî mesullük görevinin ve sorumluluğunun bulunmasına istinaden, fennî mesuliyet görevi bakımından yapı denetimi kuruluşunun İmar Kanunu hükümlerine tabi olmasının bir sonucu olarak, İmar Kanununda yer alan fennî mesuliyete ilişkin görevlerini gereği gibi yerine getirmemesi halinde yapı denetim kuruluşunun İmar Kanunu kapsamında yaptırıma tabî tutulacağı açıktır.

İmar Kanununun 42/3'üncü maddesinde, “İmar Kanununun 18, 28, 32, 33, 34, 35, 36, 37, 40 ve 41 'inci maddelerde belirtilen mükellefiyetleri yerine getirmeyen veya bu maddelere aykurı davranan (...) fennî mesullere (...) ikibin Türk Lirası, bu fiillerin çevre ve să̆lık şartlarına aykırı olması halinde dörtbin Türk Lirası, can ve mal emniyetini tehdit etmesi halinde altıbin Türk Lirası idarî para cezası verilir" hükmüne yer verilmiştir.

Kanun maddesinde yer alan ceza miktarları $2020^{55}$ y1l için sırasıyla 5.698,88 TL, 11.397,77 TL ve 17.096,66 TL' dir $^{56}$. Buna göre yapı denetim kuruluşu, fennî mesuliyet görevinden kaynaklı olarak İmar Kanununun 42/3'üncü maddesinde belirtilen mükellefiyetlerden birisini yerine getirmez ise, bu halde belediye encümeni ya da il özel idaresi encümeni kararıla fennî mesul sıfatıyla 2020 yılı için 5.698,88 TL veya 11.397,77 TL veya 17.096,66 TL para cezası verilmesi mümkündür.

\footnotetext{
53 Başbakanlık Kanunlar ve Kararlar Genel Müdürlüğü’nün 22.01.2001 tarih ve 3065 Sayılı Yazısı Eki "Yapı Denetimi Hakkında Kanun Tasarısı ve Tasarı Gerekçesi”, s.2.

54 Konya Bölge İdare Mahkemesi 2'nci İdarî Dava Dairesinin 25.02.2020 tarih ve E: 2019/2042, K: 2020/548 sayılı kararı.

552021 yılında, yeniden değerleme oranında ceza miktarları artırılarak uygulanacaktır.

56 DİLKEN, Uğur, “İmar Kanunun 42'nci Maddesi Uyarınca 2020 Yılında Uygulanacak İdarî Para Cezaları”, Mahallî İdareler Dergisi, S. 85, Ocak 2020, s.73.
} 


\section{Aynı Davranış Nedeniyle Birden Fazla Ceza Verilmesi Yönünden Konunun İncelenmesi}

Yap1 denetim kuruluşları, imar mevzuatı uyarınca verilen fennî mesuliyet görevlerini gereği gibi yerine getirmedikleri durumlarda İmar Kanununa göre; yapı denetimi mevzuatına göre verilen yap1 denetimi görevlerini gereği gibi yerine getirmedikleri durumlarda Yapı Denetimi Hakkında Kanun'a göre idarî para cezası ile karşı karşıya kalabilmektedirler. Böyle bir durumda nasıl hareket etmek gerektiği hususunda, idarî yaptırım kavramı çerçevesinde konunun ele alınması gerekmektedir. Zîra idarî para cezası, bir idarî müeyyide (idarî yaptırım) çeşididir ${ }^{57}$. Oğurlu'nun ifadesiyle konu idarî yaptırım olunca, ister istemez ceza hukukunun kavramlarına ve ceza hukukunun ilkelerine başvurmak kaçınılmaz olmaktadır ${ }^{58}$. Bu bakımdan bir inşaatın denetimi kapsamında yapı denetim kuruluşunun hem fennî mesul sıfatıyla İmar Kanununa göre hem de yapı denetim kuruluşu sıfatıyla Yapı Denetimi Hakkında Kanuna göre ceza ile karşılaşması durumunda nasıl hareket edileceğinin açıklığa kavuşturulabilmesi için, evvelâ kısaca idarî yaptırım kavramına değinilecektir.

\section{İdarî yaptırım kavramı}

Erdinç idarî yaptırımı, idarî düzeni ihlâl edenlere karşı idarenin karar verip, idarenin uyguladığı yaptırımlar olarak açıklamaktadır ${ }^{59}$. Sürbehan idarî yarptırım kavramı yerine, idarî müeyyide kavramını kullanarak; idarî müeyyideyi, idarenin aldığı kararlar ve ittihaz ettiği tedbirlerin kabulünü ve uygulanmasını sağlamak üzere kanunlara konulmuş zorlayıcı hükümler olarak açıklamaktadır ${ }^{60}$. Bu bağlamda, çerçevesi kanunlarla çizilen hallerde, araya herhangi bir yargı kararı girmeksizin, idare tarafindan yapılan inceleme/soruşturma neticesinde, yine idarece doğrudan doğruya işlem tesisi suretiyle ve idare hukukuna özgü usullerle, idare hukuku alanındaki düzene aykırı davrananlara uygulanan yaptırımlara "idarî yaptırım" $\operatorname{ad}_{1}$ verilmektedir ${ }^{61}$.

Hukuk kuralları, genel bir emri yahut yasağı içerirler ve aynı zamanda bu emre veya yasağa uymamanın yaptırımını da barındırırlar ${ }^{62}$. Aynı zamanda hukuk, kişilere bir taraftan yetkiler (haklar) verirken, diğer taraftan kişilere bazı ödevler de yüklemektedir ${ }^{63}$. Bu ödevler gereği gibi yerine getirilmez ise, kamu kudreti denilen unsur devreye girerek, o ödevin yapılmaması nedeniyle kişiye yaptırım uygulanmaktadır ${ }^{64}$. Böylelikle hem bozulan idarî düzenin düzeltilmesi, hem de kişilerin düzeni bozucu davranışlardan kaçınmaları amaçlanmaktadır. Öte yandan; kurala uymamanın cezası ve bu cezanın uygulanması şahıslara bırakılırsa, her şahıs kendince bir kural ihlâli görebilecek ve kendince bir ceza uygulayacak, bu da keyfilikle ve ölçüsüzlükle karşılaşılmasına sebep olacaktır. Bu nedenle, herkesin kabul edebileceği ortak bir otoriteye ceza verme yetkisinin verilmesi gereği ortaya çıkmış olup ${ }^{65}$; bu otoritenin kim olacağı günümüzde anayasalarla ve kanunlarla belirlenmektedir.

\footnotetext{
57 GÖZLER, Kemal, İdare Hukuku - Cilt I, Ekin Kitabevi Yayınları, Bursa, 2009, s.1080.

58 OĞURLU, Yücel, İdarî Yaptırımlar Karşısında Yargısal Korunma, Seçkin Yayınevi, Ankara, 2001 , s.16.

59 ERDİNÇ, Burcu, "İdarî Yaptırımların Kavramsal Çerçevesi ve Cezaî Yaptırımlarla Karşılaştırılması”, Ankara Barosu Dergisi, Y. 2012, S. 2, s.242.

60 SÜRBEHAN, Sadrettin, “İdarî Müeyyide Ve İdarî Ceza Hukuku”, Türk İdare Dergisi, Y. 1971, S. 328, s.133.

61 ÖZDEMİ, Selman, "İmar Para Cezaları Özelinde İdarî Yaptırımların Zaman Bakımından Uygulanması”, Türk İdare Dergisi, S. 473, Aralık 2011, s.116. ASLAN, M. Yasin, "İdarî Yaptırımlar”, Türkiye Barolar Birliği Dergisi, S. 85, 2009, s.177.

62 OĞURLU, s.20.

63 OĞURLU, s.21.

64 OĞURLU, s.21.

65 OĞURLU, s.21.
} 
İdarî yaptırımlar, idareler tarafindan idarî para cezası uygulanması, işten yasaklama, iş yerinin kapatılması, mülkiyetin kamuya geçirilmesi, ehliyetin geri alınması, yapının yıkılmasına karar verilmesi gibi idarî işlemler (tasarruflar) şeklinde tezahür ettirilmektedir ${ }^{66}$. Bu yaptırımlar, birer idarî işlem teşkil etmekle beraber, bilinen idarî işlemlerden, caydırıcıllk ve cezalandırma özelliklerine sahip olmaları nedeniyle farkl11ı arz etmektedirler ${ }^{67}$.

Diğer taraftan; idarî yaptırımlar, idarî kolluk yetkisinin kullanımı kapsamında uygulanmaktadır. Bu sebeple, kural ihlâlinin "kendiliğinden" (düzeni bozmak sureti ile) zararlı bir durum doğurduğu kabul edilmektedir ${ }^{68}$. Dolayısıyla idarî yaptırımın uygulanması için ihlâlin somut bir zarar ortaya çıkarması şart değildir. Somut bir zarar ortaya çıksa da çıkmasa da, bir kuralın ihlâli karşılığında idarî yaptırım uygulanması durumu ile karşılaşılmaktadır ${ }^{69}$.

İmar Kanununun 42'nci maddesinde düzenlenen para cezası, bir idarî yaptırımdır. Bu para cezasını verme yetkisi ise, kanun koyucu tarafından belediye ve il özel idaresi encümenlerine tevdi edilmiştir. Yapı Denetimi Hakkında Kanunun 8'inci maddesinde düzenlenen para cezası da bir idarî yaptırımdır. Bu cezayı verme yetkisi ise kanun koyucu tarafından Çevre ve Şehircilik İl Müdürlüklerine tevdi edilmiştir.

\section{Hem fennî mesuliyet hem de yapı detimi görevi nedeniyle bir firmaya "aynı fiilden dolayı" iki ayrı ceza verilip verilemeyeceğinin incelenmesi}

Bir yap1 denetim kuruluşunun, Yap1 Denetimi Hakkında Kanunda yazılı görevlerini gereği gibi yerine getirmemesi halinde Yapı Denetimi Hakkında Kanun hükümlerine göre idarî yaptırıma maruz kalacaktır. Aynı yapı denetim kuruluşu, İmar Kanununda yazılı fennî mesuliyet görevlerini gereği gibi yerine getirmemesi halinde ise (fennî mesul sıfatıyla) İmar Kanunu hükümlerine göre idarî yaptırıma idarî yaptırıma maruz kalacaktır. Bazı fiiller (hareketler) ise, hem Yapı Denetimi Hakkında Kanunda hem de İmar Kanununda kabahat olarak düzenlenmiştir. Böyle bir durumda, bir adet hareket sonucunda iki ayrı kanunun ihlâli ve iki ayrı kanun gereği yaptırımla karşılaşma durumu söz konusu olabilmektedir.

Örneğin, Yap1 Denetimi Hakkında Kanunun 2'nci maddesinin 4/g bendinde, “Ruhsat ve eklerine aykırı uygulama yapılması halinde yapı denetim kuruluşunun durumu üç iş günü içinde ilgili idareye bildirme" görevinin olduğu belirtilmiştir. Yapı Denetimi Hakkında Kanunun 8'inci maddesinde ise yap1 denetim kuruluşuna, "Hataların yapının taşıyıcı sistemini etkilememesi kaydı ile, 2 'nci maddenin dördüncü fikrasının (...) (g) bendinde belirtilen görevlerin yerine getirilmediğinin tespiti hâlinde, tespite konu olan yapı denetimi hizmet sözleşmesi bedelinin \%20'si kadar idarî para cezası verileceği"; "Hataların yapının taşıyıcı sistemini etkilemesi hâlinde 2'nci maddenin dördüncü fikrasının (...) (g) bendinde belirtilen görevlerin yerine getirilmemesi (...) hâlinde, cezayı gerektiren fiil ve hâlin yetkililer tarafindan yapılan inceleme ve denetimlerle tespit edilip ögrenilmesinden veya son idarî para cezasının tebliğinden itibaren Il Yapı Denetim Komisyonunun teklifi üzerine Bakanlıkça bir yıl yeni iş almaktan men cezası verileceği" hüküm altına alınmıştır.

Öte yandan; İmar Kanununun 32/1'inci maddesinde, “Bu Kanun hükümlerine göre; (...) ruhsat ve eklerine (...) aykırı yapı yapıldı̆̆ının (...) fennî mesulce tespiti ve ihbarı (...) üzerine, belediye veya il özel idaresince o andaki inşaat durumunun tespit edileceği ve yapının mühürlenerek inşaatın derhal

BARDAKÇI, Mehmet Akif, Kabahatler Kanununa Göre İdarî Para Cezalart ve İdarî Para Cezalarının Yargısal Denetimi, İstanbul Üniversitesi Sosyal Bilimler Enstitüsü Yüksek Tezi, İstanbul, 2006, s.24.

67 ERDINÇ, s.242.

68 OKAY TEKINSOY, Özge, "Kolluk", İdare Hukuku, YILDIRIM, Turan / YASIN, Melikşah / KAMAN, Nur / ÖZDEMIR, H. Eyüp / ÜSTÜN, Gül / OKAY TEKINSOY, Özge, XII Levha Yayınları, İstanbul, 2013, s.561. 
durdurulacağı" belirtilmiştir. Dolayısıyla İmar Kanununun 32/1'inci maddesi ile fennî mesule, bir yapının ruhsat ve eklerine aykırı yapıldığını tespit etme ve durumu derhal ilgili idareye bildirme yükümlülügü yüklenmiştir. İmar Kanununun 42/3'üncü maddesinde ise, “İmar Kanununun 32'nci maddesinde belirtilen yükümlülü̈̆̈̈ yerine getirmeyen, bir yapının ruhsat ve eklerine aykırı yapıldiğını tespit etmeyen, yahut tespit etmekle birlikte durumu derhal ilgili idareye bildirmeyen fennî mesule (...) ikibin Türk Lirası, bu fiillerin çevre ve sağlık şartlarına aykırı olması dörtbin Türk Lirası, can ve mal emniyetini tehdit etmesi halinde altıbin Türk Lirası idari para cezası verileceği”" hüküm altına alınmıştır ${ }^{70}$.

Buna göre, İmar Kanununun 32'nci maddesinde belirtilen yükümlülüğü yerine getirmeyen, yani fennî mesuliyet görevini üstlendiği bir yapının ruhsat ve eklerine aykırı yapıldığını tespit etmeyen, yahut tespit etmekle birlikte durumu derhal ilgili idareye bildirmeyen yapı denetim kuruluşuna, fennî mesuliyetten kaynaklanan bu görevi yerine getirmeme sebebiyle (2020 yılı oranları ile) 5.698,88 TL, fennî mesulün bu fiili sonucunda yapının çevre ve sağlık şartlarına aykırı olması durumunda yapı denetim kuruluşuna, fennî mesul sıfatıyla 11.397,77 TL ve fennî mesulün bu fiili sonucunda yapılan yapının can ve mal emniyetini tehdit etmesi halinde yapı denetim kuruluşuna, fennî mesul sıfatıyla 17.096,66 TL tutarında para cezası verilecektir.

Yapı Denetimi Hakkında Kanunun 8'inci maddesi ile İmar Kanununun 42'nci maddesinin ilgili hükümleri mukayeseli olarak incelendiğinde; yapının ruhsat ve eklerine aykırı yapıldığını tespit ederek bildirmeme fiilinin karşılığında,

a) Yapı denetim kuruluşu sıfatı ile firmanın Yapı Denetimi Hakkında Kanuna göre,

b) Fennî mesul sıfatı ile firmanın İmar Kanununa göre cezalandırılması durumu söz konusu olacaktır.

$\mathrm{Bu}$ durum bir simülasyon üzerinden daha somut şekilde örneklendirilebilir. A Yapı Denetim Ltd. Şti.'nin, yapı sahibi T ile imzaladığı sözleşme kapsamında, T tarafından yaptırılacak olan binanın yapı denetimi işini üstlendiğini varsayalım. Yapının B belediyesi sorumluluk sahasında olduğunu kabul edelim. A Yapı Denetim Ltd. Şti.'nin T ile imzaladığı yapı denetim sözleşmesine istinaden A Yapı Denetim Ltd. Şti., B belediyesine karşı da yapının fennî mesuliyet görevini üstlenmiştir. A Yapı Denetim Ltd. Şti. yapı denetimi görevine istinaden Yapı Denetimi Hakkında Kanun hükümlerine, fennî mesuliyet görevine istinaden İmar Kanunu hükümlerine tabi hale gelmektedir. Yapının bir bodrum kat, bir zemin kat ve 5 normal kattan oluşan bir apartman binası olduğunu; mimarî projede her bir katın yüksekliğinin $2.80 \mathrm{~cm}$ olmasına karşın, fiilen yapı kat yüksekliklerinin 2.90 m olarak inşa edildiğini, ancak bu durumun yapı tamamlandıktan sonra tespit edildiğini varsayalım. A Yapı Denetim Ltd. Şti.'nin yapıyı temelden itibaren her bir katın inşaası sürecinde kontrol ederek, bodrum kat kolonlarının ve zemin kat tabliye kalıplarının hazırlanması esnasında kat yüksekliğinin projeye aykırılığını tespit etmesi ve durumu belediyeye bildirmesi gerekmektedir. Yapı Denetimi Hakkında Kanuna göre, yapı denetim kuruluşu sıfatı ile yapı denetim firmasının durumu tespitten itibaren üç iş günü içinde belediyeye bildirmesi gerekmektedir. İmar Kanununa göre ise, fennî mesul sıfatı ile firmanın durumu tespitten itibaren gecikmeksizin (derhal) belediyeye bildirmesi gerekmektedir.

Fakat A Yapı Denetim Ltd. Şti.'nin hem Yapı Denetimi Hakkında Kanuna göre, hem de İmar Kanununa göre durumu tespit ederek belediyeye bildirmediğini Kabul edelim. A Yapı Denetim Ltd. Şti.'nin bu hareketi esasında her iki kanun bakımından aynı harekettir; bu hareket, ruhsat ve eklerine (mimarî projeye) aykırı imâlatı tespit ederek idareye bildirmeme hareketidir. 
Yapı Denetimi Hakkında Kanunda, "Hataların yapının taşıııı sistemini etkilememesi kaydı ile, 2'nci maddenin dördüncü fikrasının (...) (g) bendinde belirtilen görevlerin yerine getirilmediğinin tespiti hâlinde, tespite konu olan yapı denetimi hizmet sözleşmesi bedelinin \%20'si kadar idarî para cezası verileceği" hüküm altına alınmıştır. Yapının taşıyıcı sistemi etkilenmekte ise, bu durumda yapı denetimi kuruluşuna, yapı denetimi hizmet sözleşmesi bedelinin \%20'si kadar idarî para cezası değil, "bir yıl yeni iş almaktan men cezası" verilecektir.

Fennî mesuliyet görevine istinaden ise (projeye aykırı imalatın can ve mal güvenliğini tehdit etmesi halinde) A Yapı Denetim Ltd. Şti.'ye (2020 yılı oranına göre) 17.096,66 TL para cezası verilecektir. Böyle bir durumda A Yapı Denetim Ltd. Şti.'ne aynı fiil nedeniyle Çevre ve Şehircilik İl Müdürlüğü tarafindan "hizmet sözleşmesi bedelinin \%20'si kadar idarî para cezası" veya (şartları mevcutsa) "bir yıl yeni iş almaktan men cezası"; belediye encümeni tarafından karşılık geldiği fiilin niteliğine göre "5.698,88 TL" veya "17.096,66 TL para cezası" verilmesi durumu söz konusu olacaktır. Bu durum ise, aynı fiil nedeniyle A Yapı Denetim Ltd. Şti.'nin iki kere idarî yaptırım ile cezalandırılması sonucunu ortaya çıkaracaktır. Böyle bir durumda, aşağıda yer verilen içtima müessesesi çerçvesinde konunun ele alınması gerekmektedir.

\section{"Non bis in idem" kuralt}

Hem İmar Kanununda hem de Yapı Denetimi Hakkında Kanunda, bir kısım fiillerin karşıllı̆g hem idarî müeyyide, hem de adlî müeyyide olarak techiz edilmiştir. İdarî yaptırımların müsebbibi olan kural ihlâllerinin "kabahat" kabul edilmelerine karşın; her ikisi de hukuk kuralını ihlâl etmek suretiyle ortaya çıkan kabahat ve suç kavramları kimi zaman karıştırılmaktadır. Bu karıştırılma durumu sebebiyle İmar Kanunu ve Yapı Denetimi Hakkında Kanun bakımından "non bis in idem" kuralı konusuna değinilmeden evvel, kabahat kavramı ile suç kavramına kısaca değinmenin uygun olduğu değerlendirilmiştir.

Bir fiilin kabahat olarak nitelenmesinin temel ayırıcı özelliği; kabahatlerde zarurî olarak, özel bir kişi hakkının/menfaatinin veya özel bir kamu hakkının/menfaatinin ihlâlinin yahut tehdidinin söz konusu olmaması halidir ${ }^{71}$. Kabahatlerde, gayesi sosyal menfaatlerin veya varlıkların himayesi olan bir hukuk normunun ihlâli söz konusudur ${ }^{72}$. Ancak, bu varlıklar veya menfaatler, kişiye ait (özel/subjektif) hakları/menfaatleri teşkil etmemektedir. Bunlar, sadece objektif şekilde (devlet tarafından genel ve objektif olarak) hukuken himaye edilen varlıklar veya menfaatlerdir ${ }^{73}$. Ancak yapılan ihlâl (kamu düzeni, kamu sağlı̆̆ gibi) genel/objektif şekilde korunan varlıklara veya menfaatlere değil de; (kişi hakları, devlet sırları gibi) sübjektif/özel olarak korunan varlıklara veya menfaatlere yönelmiş ise; bu durumda ihlâlin kaynağı olan fiil, suç niteliğine bürünecektir. Nitekim önem arz eden (yani sübjektif/özel menfaate yönelmiş olan) bazı kabahat niteliğindeki fiillerin müeyyidesi adlî nitelikli ceza olarak öngörülmüştür ki; bunlardan birisi Türk Ceza Kanununun 123'üncü maddesinde düzenlenen "kişilerin huzur ve sükûnunu bozma" fiilidir" bu fiil özel olarak suç niteliğinde düzenlenmiştir ${ }^{75}$. Dolayısıyla aynı fiil hem toplumun genel menfaatlerine, hem de özel bir menfaate zarar verebilir ve fiilin toplumun genel menfaatine vermiş olduğu zarar dolayısıyla idarî müeyyide yolu ile fiili işleyen tecziye edilebileceği gibi; fiilin özel bir menfaate zarar vermesi

\footnotetext{
71 TOROSLU, Nevzat, Cürümlerin Tasnifi Bakımından Suçun Hukukî Konusu, Ankara Üniversitesi Hukuk Fakültesi Yayınları, Ankara, 1970, s. 98.

72 TOROSLU, s. 98.

73 TOROSLU, s. 98.

74 AÇIKGÖZ, Ali Nevzat, Gerekçeli - Karşılaştırmalı - Açıklamalı Yeni Türk Ceza Kanunu, (Kendi Yayını), Van, 2005, s. 393.

75 Diğer taraftan, idarî yaptırımların müsebbibi niteliğindeki fiiller suçtan ziyade kabahat niteliğinde olmakla birlikte; bir fiilin aynı zamanda suç olması hususu o fiile ilişkin idarî yaptırım uygulanamayacağı anlamına gelmemekte olduğundan; her idarî nitelikli fiil bir suç olmayabilirken; her suç bir idarî nitelikli fiilin ihlâli sonucunu doğurabilmektedir.
} 
dolayısıyla da fail adlî müeyyide ile de tecziye edilebilir ki; bu iki alanın birbirinden ayrı ve bağımsız olmasının doğal bir sonucu olarak "non bis in idem" kuralı, adlî ve idarî uygulamalarda kural olarak dikkate alınmaz ${ }^{76}$. Ancak bu durumun istisnasının kanun koyucu tarafindan belirlenmesi elbette mümkündür. Nitekim Kabahatler Kanununda ${ }^{77}$ ve İmar Kanununda ${ }^{78}$, adlî ve idarî cezalar bakımından "non bis in idem" kuralına ilişkin istisnaî hükümlere yer verilmiştir.

Fennî mesuliyet sıfatı dolayısıyla bir yapı denetim kuruluşunun hem adlî hem de idarî ceza ile karşılaşması; kezâ yapı denetim görevi dolayısıyla bir yapı denetim kuruluşunun hem adlî hem de idarî ceza ile karşılaşılması söz konusu olabilir. Böyle bir durumda ne şekilde hareket edileceği hususları, bu çalışmanın inceleme konusu dışında kalmaktadır. Bu çalışmada non bis in idem kuralı bağlamında incelenecek husus, bir firmaya hem fennî mesuliyet görevi hem de yapı denetim görevi kapsamında, "aynı fiil nedeniyle" iki adet idarî yaptırım uygulanıp uygulanamayacağı hususudur.

"Aynısı için iki kez olmaz" şeklinde çevirisi yapılan79, fiilin aynılı̆̆ ve kişinin aynılığı olmak üzere iki unsuru bulunan "non bis in idem" kavramı; aynı kişi hakkında aynı fiil nedeniyle birden çok ceza verilmemesini ihtiva etmektedir ${ }^{80}$. Bu ilke (adlî) ceza hukuku alanında mutlak olarak uygulanmaktadır ${ }^{81}$. Bu ilkenin idarî ceza hukuku alanında, mutlak manâda uygulama alanı bulduğunu söylemek güçtür.

Ekinci, idarî tedbir ve idarî yaptırım ayrımına giderek, aynı fiil nedeniyle hem idarî yaptırım hem de idarî tedbir uygulanmasının mümkün olduğunu ifade etmektedir ${ }^{82}$. Aslında bu duruma mevzuat cevaz vermektedir. Ekinci, idarî tedbirler teknik olarak ceza niteliğinde sayılmadığı için, aynı fiil nedeniyle hem idarî yaptırım hem de idarî tedbir uygulanması halinde non bis in idem ilkesine aykırı bir durumun, yani birden fazla cezalandırma durumunun söz konusu olmayacağını belirtmektedir ${ }^{83}$. Ekinci, mevzuata aykırı faaliyette bulunan bir işyerine hem idarî para cezası verilip hem de geçici olarak işyerinin kapatılması, işyerinin mühürlenmesi veya işyerinin faaliyetten men edilmesi durumunu bu konuya örnek olarak göstermektedir ${ }^{84}$.

GÖLCÜKLÜ, Feyyaz, "İdarî Ceza Müeyyideleri ve Bunlara Karşı Kanun Yolları”, Ankara Üniversitesi Siyasal Bilgiler Fakültesi Dergisi, C. 18, S. 3-4, Y. 1963, s. 212.

Kabahatler Kanununun 15/3'üncü maddesinde, "Bir fiil hem kabahat hem de suç olarak tanımlanmış ise, sadece suçtan dolayı yaptırım uygulanabilir. Ancak, suçtan dolayı yaptırım uygulanamayan hallerde kabahat dolayısıyla yaptırım uygulanır" hükmüne yer verilerek, adlî ceza ve idarî cezaya ilişkin non bis idem kuralının uygulama esasları belirtilmiştir. KART, Aslıhan / KETIZMEN, Muammer, "Kabahatler Kanunu'nun İçtima Hükümleri Açısından Kişisel Verilerin Korunmasına İlişkin Suç ve Kabahatler ile Kurul'un İdarî Ceza Kararlarına İlişskin Bir Değerlendirme", Kişisel Verileri Koruma Dergisi, C. 1, S. 2, Y. 2019, s.19.

Bu durumun istisnası olarak addedilebilecek bir diğer duruma da İmar Kanununun 42/7 nci fikrası örnek olarak gösterilebilir. İmar Kanununun 42'nci maddesine göre idarî para cezası verilen kişiden para cezasının tahsil olunması sonrasında, kişi aynı fiil nedeniyle Türk Ceza Kanununun 184 üncü maddesine göre mahkûm olmuş ise, bu kişilere tahsil olunan para cezası faizsiz olarak iade edilecektir.

CEBECI, Şeyma, Türk Ceza Hukuku Bağlamında Ne Bis In Idem İlkesi, İstanbul Bilgi Üniversitesi Yüksek Lisans Tezi, İstanbul, 2018, s.3.

ÖZEN, Mustafa, "Non Bis İn İdem (Aynı Fiilden Dolayı İki Kez Yargılama Olmaz) İlkesi”, Gazi

Üniversitesi Hukuk Fakültesi Dergisi, C. 14, Y. 2010, s.391.

KURT, Hayrettin, “İdarî Yaptırımlara Karşı Güvenceler”, Gazi Üniversitesi Hukuk Fakültesi Dergisi, C. 18, Y. 2014, s.168.

EKİNCİ, Murat, “Ceza Hukuku Açısından İdarî Yaptırımlar”, Yıldırım Beyazıt Hukuk Dergisi, Y. 2017, S.

3, s.46.

EKINCI, s.46.

EKINCI, s.46. 
$\mathrm{Bu}$ ilke idarî yaptırımlar alanında mutlak olarak kabul edilmemekle birlikte, kısmî olarak idarî yaptırımlar alanında bu ilkenin uygulama alanı bulduğundan söz edilebilirr ${ }^{85}$.

Kabahatler Kanununun hazırlanmasının sebeplerinden birisi de, idarî yaptırımlarla ilgili olarak ülkemizde genel bir kanuna ihtiyaç duyulmasıdır ${ }^{86}$. Bu kapsamda, Kabahatler Kanununa "Genel Kanun Niteliği”" şeklinde bir madde başlığ konulmuştur. Bu maddede, "Bu Kanunun; (...) genel hükümleri, idarî para cezası veya mülkiyetin kamuya geçirilmesi yaptırımını gerektiren bütün fiiller hakkında uygulanır" hükmüne yer verilmiştir (m.3).

Maddeye göre, sadece idarî para cezası yaptırımı ile sadece mülkiyetin kamuya geçirilmesi yaptırımı gerektiren fiiller bakımından, Kabahatler Kanununun idarî yaptırım içeren kanunlar için genel kanun olarak düzenlendiği ve bu hususlar bakımından Kabahatler Kanununun genel hükümlerinin, diğer mevzuat alanında da uygulanacağı anlaşılmaktadır.

Esasında, kaç adet kanun maddesinin ihlâli mevcut ise, o kadar sayıda kabahatten bahsetmek ve her bir kanun hükmü ihlâline ayrı ayrı yaptırım uygulamak mümkündür. Ancak kanun koyucu bazen birden çok ihlâli tek kabahat sayarak, faile tek ceza verilmesini öngörebilmektedir ${ }^{87}$. İşte bu tür bir düzenlemeye Kabahatler Kanununda da yer verildiği görülmekte olup; birden çok ihlâl olmasına rağmen faile tek ceza verilmesi müessesesinin adına, içtima denilmektedir.

İdarî para cezası içeren kanunlar bakımından dikkate alınması gereken Kabahatler Kanununun "Genel Hükümleri" arasında yer alan 15'inci maddede, "içtima" müessesesine yer verilmiştir. Kabahatler Kanununun 15/1'inci maddesinde, "Bir fiil ile birden fazla kabahatin işlenmesi halinde bu kabahatlere ilişkin tanımlarda sadece idarî para cezası öngörülmüşse, en ăğr idarî para cezast verilir. Bu kabahatlerle ilgili olarak kanunda idarî para cezasından başka idarî yaptırımlar da öngörülmüs ise, bu yaptırımların her birinin uygulanmasına karar verilir" hükmüne yer verilmiştir.

Bu hükmün, Türk Ceza Kanununun farklı nev'iden fikrî içtimaya ilişkin hükmüne paralel bir düzenleme olduğu anlaşılmaktadır ${ }^{88}$. Ancak Kabahatler Kanunundaki bu hüküm, sadece idarî para cezaları açısından uygulanabilmektedir ${ }^{89}$. Bu itibarla, bir fiille gerçekleştirilen birden fazla kabahatten her birisi açısından idarî para cezası dışında başka idarî yaptırımlar öngörülmüş ise, bu yaptırımların hepsine ayrı ayrı karar verilmesi gerekmektedir ${ }^{90}$.

\section{“Non bis in idem” kuralı bakımından 20 Şubat 2020 tarihinden önceki durum}

20 Şubat 2020 tarihinde 7221 sayılı Coğrafi Bilgi Sistemleri İle Bazi Kanunlarda Değişiklik Yapılması Hakkında Kanun yürürlüğe girmiştir ${ }^{91}$. Bu Kanun ile muhtelif kanunlarda değişilikler yapıldığı gibi, Yapı Denetimi Hakkında Kanunda da değişiklikler yapılmıştır.

85 EKİNCí, s.47.

86 Giş̧i, Selçuk, "Kabahatleri Suç Olmaktan Çıkarma Eğilimi Ve Kabahatler Kanunu”, İnönü Üniversitesi Hukuk Fakültesi Dergisi, C. 8, S. 1, Y. 2017, s.136.

87 TOROSLU, Nevzat, Ceza Hukuku, Savaş Yayınevi, Ankara, 2005, s.230.

88 YURTCAN, Erdener, Yargıtay Kararları Işığında Kabahatler Kanunu ve Yorumu, Türkiye Barolar Birliği Yayınları, Ankara, 2016, s.99.

89 YURTCAN, s.99.

90 BEKÂR, Elif, "Kabahatler Kanunu'nun Genel Hükümlerinin Değerlendirilmesi”, İstanbul Üniversitesi Hukuk Fakültesi Mecmuası, C. 69, S. 1-2, s.1049. YURTCAN, s.99.

917221 sayılı Kanun ile ilgili değişiklikler hakkında bkz. BILGiN, Hüseyin, "7221 sayı1lı Kanunla3194 sayı1ı Kanunda Yapılan Değişiklikler Hakkında Bir İnceleme”, Mahallî İdareler Dergisi, Mayıs-Haziran 2020, S. 89-90, s.10-34. 
Yukarıda yer verilen açıklamalar bağlamında konu ele alındığında, söz konusu değişiklik öncesindeki durumda; aynı fiil nedeniyle fennî mesuliyet sıfatı kapsamında İmar Kanununa göre, yapı denetim görevi kapsamında Yapı Denetimi Hakkında Kanuna göre aynı firmaya ayrı ayrı yaptırım uygulanıp uygulanamayacağı, her bir yaptırımın türüne göre netleşecektir.

Yapı denetim kuruluşuna uygulanacak olan yaptırım hem İmar Kanununda hem de Yapı Denetimi Hakkında Kanunda para cezası olarak düzenlenmiş ise, bu halde ağır olan ceza hangisi ise, bu cezanın verilmesi gerekmektedir. Örneğin Yapı Denetimi Hakkında Kanundaki ceza ağır ise, bu halde belediye encümeninin İmar Kanununa göre ceza vermemesi; İmar Kanunundaki ceza ağır ise, bu halde de çevre ve şehircilik il müdürlüğünün ceza vermemesi gerekmektedir. Şayet her iki idare de ceza vermiş ve her iki cezanın iptali talebi ile dava açılmış ise, bu durumda idare mahkemesince hafif olan ceza hangisi ise, o cezanın "içtima hükümleri kapsamında" iptaline karar verilmesi gerekmektedir. Neden böyle bir uygulma yapılmalıdır? Çünkü, Kabahatler Kanunununun genel hükümleri arasında yer alan içtima müessesesi, Kabahatler Kanununun 3'üncü maddesi gereği İmar Kanunu ve Yapı Denetimi Hakkında Kanun uygulamasında da göz önünde bulundurulmak zorundadır.

Ancak fiile, İmar Kanununa göre fennî mesul sıfatıyla para cezas1, Yapı Denetimi Hakkında Kanuna göre ise yapı denetimi görevi nedeniyle para cezası haricinde başka bir yaptırım (örneğin bir yıl yeni iş almaktan men cezası) uygulanacak ise, bu durumda Kabahatler Kanunu gereği içtima hükümleri uygulanmayacak; her bir ceza ayrı ayrı verilip ayrı ayrı infaz edilecektir.

\section{“Non bis in idem” kuralı bakımından 20 Şubat 2020 tarihinden sonraki durum}

Yukarıda yer verilen değerlendirmeler, 20 Şubat 2020 tarihinden önce verilen ve belirtilen tarihten önce kesinleşen cezalar bakımından geçerli olacaktır. 20 Şubat 2020 tarihinden sonra verilen cezalar ile 20 Şubat 2020 tarihinden önce verilmekle birlikte henüz kesinleșmemiș (dava konusu edilmiș ve davaları devam eden) cezalar bakımından ise uygulamanın aşağıda açıklanan biçimde yürütülmesi gerektiği değerlendirilmektedir.

20 Şubat 2020 tarihinde yürürlüğe giren 7221 sayılı Coğrafî Bilgi Sistemleri İle Bazı Kanunlarda Değişiklik Yapılması Hakkında Kanun ile içtima müessesesi ile ilgili yeni ve Kabahatler Kanununa göre özel nitelikte bir düzenlemenin getirildiği görülmektedir. 7221 sayılı Kanun ile Yapı Denetimi Hakkında Kanuna bir fikra eklenerek, Yapı Denetimi Hakkında Kanun kapsamındaki yapı denetim sorumluluğu ile yapı denetim firmasının İmar Kanunundaki fennî mesuliyet sorumluluğu bakımından cezaî sorumluluğa ilişkin düzenleme yapılmıştır.

7221 sayılı Kanunun genel gerekçesinde konuya ilişkin olarak, “(...) şehircilik alanında (...) temel kanunlar olan 3194 sayılı İmar Kanununda, 3621 sayılı Klyı Kanunda, 4708 sayılı Yapı Denetimi Hakkında Kanunda, 5543 sayılı İskân Kanunda ve diğer bazı kanunlarda değiş̧iklik yapılması ihtiyacı doğmuştur ${ }^{92}$. (...) fiil-yaptırım dengesi gözetilerek görevini mevzuata uygun yerine getirmeyen sorumlulara ilişskin idarî müeyyideler yeniden düzenlenmektedir. Kanunun ceza maddesi daha açık ve net hale getirilerek tereddütlerin ortadan kaldırılması amaçlanmaktadır" açıklamasına yer verilmiştir ${ }^{93}$.

Kabahatler Kanununun "Genel Hükümleri” arasında, zaman bakımından uygulamanın nasıl olacağına ilişkin kurallara yer verilmiştir. Kabahatler Kanununun "Zaman Bakımından Uygulama” başlıklı 5/1'inci maddesinde, "5237 sayıl Türk Ceza Kanunu'nun zaman bakımından uygulamaya ilişkin

92 TBMM, İstanbul Milletvekili Mustafa Demir ile 70 Milletvekilinin Coğrafi Bilgi Sistemleri ile Bazı Kanunlarda Değişiklik Yapılması Hakkında Kanun Teklifi (2/2512) ve Bayındırlık, İmar, Ulaştırma ve Turizm Komisyonu Raporu, s.6, https://www.tbmm.gov.tr/sirasayi/donem27/yil01/ss161.pdf, erişim tarihi 22.05.2020. 
hükümlerinin kabahatlar bakımından da uygulanacağı" hüküm altına alınmıştır. İdarî yaptırımlarda zaman bakımındna uygulama için yollama yapılan 5237 sayılı Türk Ceza Kanunu'nun "Zaman Bakımından Uygulama" başlıkl1 7/2'nci maddesinde ise, "suçun işlendiği zaman yürürlükte bulunan kanun ile sonradan yürürlüge giren kanunların hükümleri farklı ise, failin lehine olan kanunun uygulanacă̆ ve infaz olunacağı" hükmüne yer verilmiştir.

Buna göre kabahat fiili işlendikten sonra, kabahat fiiline karşılık uygulanacak yaptırımla ilgili olarak bir kanun yürürlüğe girmiş ise, sonraki kanun failin aleyhineyse geriye yürümeyecek, kendinden önceki fiile tesir etmeyecektir. Ancak sonraki kanunda fail lehine bir durum ortaya çıkıyorsa, yeni kanun geriye yürüyecek, fiilin işlendiği zaman yürürlükte olmasa dahi olayda uygulama alanı bulacaktır ${ }^{94}$. Fiil işlendikten ve tespit edildikten sonra lehe olacak bir kanun hükmü yürürlüğe girmiş ise, bu halde zaman bakımından uygulamaya ilişkin hükmün, ceza(lar) verilmeden önce idare tarafından dikkate alınması gerekmektedir. İdare tarafından verilen cezaların iptali talebiyle dava açılmış, dava derdest ve yargısal açıdan ceza(lar) henüz kesinleşmemiş ise, bu durumda zaman bakımından uygulamaya ilişkin kuralın mahkeme tarafindan göz önünde bulundurulması icab etmektedir.

20 Şubat 2020 tarihinde yürürlüğe giren 7221 sayılı Kanunun 25'inci maddesi ile Yapı Denetimi Hakkında Kanunun 8'inci maddesine eklenen son fikrada "Bu Kanun ve ilgili mevzuata göre görevini yerine getirmeyen yapı denetim kuruluşları hakkında bu madde uyarınca idari para cezası uygulanmasını gerektiren fiillerin tespiti halinde ayrica 3194 sayılı Kanun uyarınca idari para cezast uygulanmaz" hükmüne yer verilmiştir.

Söz konusu fikranın gerekçesinde ise, "Aynı ihlalin karşılı̆̆ı olarak hem 3194 sayılı Kanunda hem de 4708 sayılı Kanunda farklı cezalar öngörüldüğ̈̈nden, mükerrerliği önlemek amaclyla özel kanun niteliğinde olan 4708 sayılı Kanundaki idarî para cezalarının uygulanması amaçlanmaktadır" açıklamasına yer verilmiştir ${ }^{95}$.

$\mathrm{Bu}$ düzenlemelere göre, yapı denetim kuruluşunun mevzuata aykırı fiili hakkında, hem Yapı Denetimi Hakkında Kanunda hem de İmar Kanununda ceza öngörülmüş ise, bu durumda sadece Yapı Denetimi Hakkında Kanuna göre ceza verilecek, İmar Kanununa göre ceza verilemeyecektir. Yapı denetim kuruluşunun mevzuata aykırı fiili hakkında, Yapı Denetimi Hakkında Kanunda ceza öngörülmemiş ise, bu durumda fennî mesul sıfatıyla yapı denetim kuruluşuna İmar Kanununa göre ceza verilecektir.

Ancak bu maddenin uygulanabilmesi için, yapı denetim kuruluşunun fiilinin her iki Kanunda da kabahat (idarî suç) olarak düzenlenmiş olması gerekmektedir. Fiil, her iki kanunda da aynı kabahat (idarî suç) olarak düzenlenmemiş ise, bu halde de her iki Kanuna göre ceza uygulanması mümkündür.

Konuya ilişkin bir olayda, bir yapı denetim şirketi, bir yapının Yapı Denetimi Hakkında Kanun'a göre yapı denetimi işini üstlenmiştir. Şirket, Yapı Denetimi Hakkında Kanunun 3'üncü maddesi gereği, bu yapının aynı zamanda fennî mesulüdür. Yapıda yapılan inceleme sonrasında, yapı müteahhidine şirket tarafından 03.08.2018 tarihinde bir yazı yazılmıştır. Yazıda özetle "inşaatın temel çukurunda toprak kayması riskinin bulunduğu ve tehlike arz ettiği; oluşacak herhangi bir kaza sonucunda can ve mal kaybına mahal vermemek adına gerekli tedbirlerin alınması gerektiği; 45 iş günü içinde gerekli tedbirler alınmaz ise Yap1 Denetimi Hakkında Kanun'a istinaden durumun ilgili idareye bildirimde bulunularak, idare tarafından inşaatın durdurulacağı" belirtilmiştir. Yapı denetim kuruluşu olan şirket, 08.10.2018 tarihinde (...) Belediye Başkanlığı İmar ve Şehircilik Müdürlügü'ne başvurularak, “müteahhitliğini (...) İnşaat Ltd.

94 TULAY, Muhammed Emre, "Kanunilik İlkesi Işı̆̆ında Ceza Hukuku Kurallarının Zaman Bakımından Uygulanması Ve Delil Elde Etme Yöntemlerinde Zaman Bakımından Uygulanma Sorunu”, Marmara Üniversitesi Hukuk Fakültesi Hukuk Araştırmaları Dergisi - Cevdet Yavuz'a Armağan, C. 22, S. 3, Y. 2016, s.2721. 
Şti.'nin üstlendiği (...) sayılı parselde inşa edilen yapının inşaatının temel kazısı işlemleri gerçekleştirilirken, iş ve işçi sağlığı ile çevre binaların olumsuz yönde etkilenmemesi için gerekli önlemlerin alınması için müteahhide 45 iş günü süre tanınmasına rağmen, tanınan sürenin dolduğu tarih itibariyle müteaahit tarafindan halen gerekli tedbirlerin alınmadı̆ğ" belediyeye bildirilmiştir.

Yapı denetim kuruluşu olan şirket tarafindan belediyeye yapılan bildirim üzerine belediye tarafından mahallinde denetim yapılarak inşaat \%15 seviyede iken mühürlenmiştir. Mühürleme sonrasında belediye encümeni fennî mesul sıfatıyla yapı denetim şirketine para cezası vermiştir.

Cezanın iptali talebi ile açılan davada ilk derece mahkemesi cezanın iptaline karar vermiştir ${ }^{96}$. İstinaf incelemesinde ise yapı denetim kuruluşunun aynı zamanda fennî mesul sıfatının bulunduğu vurgulandıktan sonra, istinaf mahkemesi dairesi, "Nüfus yoğunluğunun ve buna bağlı yapılaşma sayısının artması ile birlikte yerleşim yerlerinde, arsa sınırlarında, eğimli alanlarda, bitişik nizam yapıların bulunduğu alanlarda ve/veya yola sınırı bulunan bölgelerde yeni yapılan yapıların inşası aşamasında ve öncesinde gerekli tedbirlerin alınarak, mevcut komşu yapılara, yollara ve alt yapıya zarar vermeden inşa çalışmalarının yürütülmesi gerekmektedir. Yapı inşasının bulunduğu alanlarda ihmal sonucu veya tedbirlerin yeterince alınmamasına istinaden, inşaata bitişik nizamda bulunan veya inşaat alanı yakınında olan diğer yapılarda, park etmiş araçlarda, alt yapıda zararların oluştuğu yahut da zararların oluşma riskinin mevcut olduğu; bu durumun ise hem çevre sakinleri hem de inşaatta çalışan kişilerin can ve mal güvenliklerini tehlikeye attığı, riskin gerçekleşmesi sonucunda ise maddî ve manevî kayıpların ortaya çıkmasına sebep olunduğu bilinmektedir" açıklamalarına yer vermiştir ${ }^{97}$.

Ardından daire, "Söz konusu tehlikeli durumların ortaya çıkmasının önüne geçilmesi maksadıyla ilgililerin mevzuattaki güvenlik tedbirlerini almast zorunludur. İmar Kanunu ve Plânlı Alanlar Imar Yönetmeliği gereği, can ve mal kaybının önüne geçilmesi ve tehlike halinin önlenmesi maksadıyla, mevzuattaki tedbirlerin gereğ $i$ gibi alınmadı̆̆ının ve tehlike halinin mevcut olduğunun anlaşlması durumunda fennî mesulün tehlike halinin varlı̆̆ını gecikmeksizin - derhal (Imar Kanunu'nun 28/2'nci maddesine göre, kabul edilebilir mazeretler varsa, en geç 6 iş günü içinde) belediyeye bildirmesi gerekmekte olup; olayda, fennî mesul davacının tehlike arz eden durumdan 03.08.2018 tarihi itibariyle haberdar olmasına karşın, belediyeye durumu 08.10.2018 tarihinde bildirdiği dikkate alındiğında; davacının fennî mesul olarak İmar Kanunu'nun 28/2'nci maddesindeki ve Plânlı Alanlar İmar Yönetmeliğindeki mükellefiyetini mevzuata uygun şekilde yerine getirmediği, bu duruma istinaden mükellefiyeti yerine getirmeme fiilinin sübuta erdiği sonucuna varılmıştır." açıklamalarına yer vermiştir ${ }^{98}$.

Temel kazısı esnasında toprak kayması riskinin bulunması ve bununda komşu yapılara, yola ve diğer alt yapıya zarar verme tehlikesi durumunu gecikmeksizin bildirmeyen yapı denetim kuruluşunun, bu bildirimi 66 gün sonra yapmış olmasının mevzuata aykırı bir davranış olduğu tespiti yapıldıktan sonra istinaf mahkemesi konuyu ayrıca 20 Şubat 2020 tarihinde yürürlüğe giren Yapı Denetimi Hakkında Kanunun 8'inci maddesine eklenen son fikrada yer alan "Bu Kanun ve ilgili mevzuata göre görevini yerine getirmeyen yapı denetim kuruluşları hakkında bu madde uyarınca idari para cezası uygulanmasını gerektiren fiillerin tespiti halinde ayrıca 3194 sayıl Kanun uyarınca idari para cezası uygulanmaz" hükmü kapsamında da değerlendirmiş; bu kapsamda maddî olaydaki fiilinin, Yapı Denetimi Hakkında Kanuna göre idarî para cezası uygulanmasını gerektiren bir fiil olup olmadığı ele alınmıştır.

\footnotetext{
$96 \quad$ Adana 2'nci İdare Mahkemesinin 18.06.2019 tarih ve E: 2019/61, K: 2019/540 say1l karar1.

97 Konya Bölge İdare Mahkemesi 2'nci İdarî Dava Dairesinin 25.02.2020 tarih ve E: 2019/2042, K: 2020/548 sayılı kararı.

98 Konya Bölge İdare Mahkemesi 2’nci İdarî Dava Dairesinin 25.02.2020 tarih ve E: 2019/2042, K: 2020/548 sayılı kararı.
} 
Bölge idare mahkemesi dairesi, "Davacının cezalandırllmasına esas olan çevre güvenliği, alt yapı güvenliği, civardaki binaların toprak kaymasına istinaden zarar görme tehlikesi altında bulunması durumunun kural olarak gecikmeksizin/derhal (makul mazeretler varsa en geç altı iş günü içinde) belediyeye bildirilmesi mükellefiyeti ile Yapı Denetimi Hakkında Kanunun 2 'nci maddesinde sayılan fiiller mukayeseli olarak incelendiğinde; Yapı Denetimi Hakkında Kanunun 2/4 üncü maddesinin (f) bendinin, davacı şirketin cezalandırılmasına esas fiile en yakın fiil olduğunu, Yapı Denetimi Hakkındaki Kanunda yer alan diğer bentlerin ise olayda davacının cezalandırılmasına esas fiil ile ilgili olmadı̆̆ııı" belirtmiştir99.

Ardından, "Yapı Denetimi Hakkında Kanunun 2/4 üncü maddesinin (f) bendinin içeriğinde ise işyerinde çalışanların iş sağllğ ve güvenliği ile ilgili durumun düzenlediği, ancak davacı şirketin cezalandırılmasına esas durumun çevredeki binaların ve altyapının toprak kaymasından zarar görme ihtimalini de esas aldı ̆̆, bu nedenle davact şirketin cezalandırllmasına esas durumun Yapı Denetimi Hakkında Kanunun 2/4 üncü maddesinin (f) bendi ile de ilgisinin bulunmadiğg, zîra her iki durumun tehlikenin sonuçları ve oluşan zararlar bakımından farklı halleri kapsama aldiğı anlaşıldığından; fiilin Yapı Denetimi Hakkında Kanunun 8'inci maddesine eklenen son fikra kapsaminda kalmadiğ l, bu nedenle şirkete fennî mesul sıfatıyla İmar Kanununa göre ceza verilmesinin hukuken mümkün olduğu, cezaî işlemde içtima hükümleri ve zaman bakımından uygulama kuralları bakımından hukuka aykırılık bulunmadı̆̆gl" gerekçesine yer verilerek ilk derece mahkemesi kararı kaldırılmıştır ki; bize göre kararda hukuka uygun bir değerlendirme yapılmıştır.

Yapı denetim kuruluşunun, projeye aykırı inşaî faaliyeti bildirmeme nedeniyle cezalandırılması halinde durum değişecektir. Zîra Yapı Denetimi Hakkında Kanunun 2/4 üncü maddesinin (c) bendinde, "Yapının, ruhsat ve ekleri ile mevzuata uygun olarak yapılmasını denetlemek" görevi yapı denetim kuruluşu görevleri arasında sayılmış; 8'inci maddede ise projeye aykırılı̆̆ın denetlenmeyerek idareye bildirilmemesi, cezaî yaptırıma tabi tutulmuştur. Bu bakımdan, şayet fennî mesul sıfatıyla projeye aykırıllı̆g idareye bildirmeme nedeniyle İmar Kanununa göre yapı denetim kuruluşuna ceza verilse idi, bu halde 20 Şubat 2020 tarihinde yürürlüğe giren düzenleme kapsamında konunun ele alınmasının mümkün olduğu anlaşılmaktadır.

Sonuç olarak 20 Şubat 2020 tarihinde yürürlüğe giren düzenlemeye göre, yapı denetim kuruluşuna sadece Yapı Denetimi Hakkında Kanuna göre ceza verilebilmesi ve İmar Kanunu kapsamında ceza uygulanamaması için, yapı denetim kuruluşunun fiilinin her iki Kanunda da kabahat (idarî suç) olarak düzenlenmiş olması gerekmektedir. Her iki kanun bakımından fiil aynı fiil değil ise, kezâ fiil, her iki kanunda da aynı kabahat (idarî suç) olarak düzenlenmemiş ise, bu halde her iki Kanuna göre ceza uygulanmasının hukuken mümkün olduğu değerlendirilmektedir.

\section{SONUC}

Yapı denetimi, geniş anlamda idarenin imar kolluğu faaliyetleri kapsamında takip ettiği görevleri arasında yer almaktadır. Kanun koyucu, yapı denetimi işinin sahada tatbikinin özel firmalar eli ile yürütülmesini öngörmüştür. Ancak özel firmaların yapı denetimi işini yürütmeleri, belediyelerin ve il özel idarelerinin denetim yetkilerini de kaldırmamıştır.

Öte yandan; yapı denetim kuruluşlarına kanun koyucu aynı zamanda imar mevzuatına göre fennî mesuliyet görevini tevdi etmiştir. Dolayısıyla yapı denetimi işini üstlenen firma, aynı zamanda fennî mesuliyeti de üstlenmektedir. 
Yap1 denetimi görevinin Yapı Denetimi Hakkında Kanunda yer alan kurallara uygun şekilde yapılmaması halinde, yapı denetimi firmasına Yapı Denetimi Hakkında Kanun hükümlerine göre idarî yaptırım uygulanması; fennî mesuliyet görevinin ise imar mevzuatında yer alan kurallara uygun şekilde yapılmaması halinde ise, yine aynı firmaya bu kez fennî mesul sıfatı ile İmar Kanunu hükümlerine göre idarî yaptırım uygulanması söz konusu olmaktadır.

Fennî mesuliyet görevinin mevzuata uygun şekilde yapılmamasına istinaden İmar Kanununun 42’nci maddesi gereği belediye yahut il özel idaresi encümeni tarafından verilen para cezalarına karşı açılan davalarda yargının genel tutumunun, firmanın ticaret unvanında "yapı denetim şirketi" yazması nedeniyle, yapı denetim şirketine İmar Kanununa göre ceza verilemeyeceği, Yapı Denetimi Hakkında Kanuna göre ceza verilebileceği gerekçesi ile, İmar Kanununa göre verilen cezaların iptali yönünde olduğu gözlenmektedir.

Bize göre, şirketin unvanında "yapı denetim şirketi” yazması, bu şirkete İmar Kanunu kapsamında ceza verilemeyeceği anlamına gelmemektedir. Zîra Yapı Denetimi Hakkında Kanun açıkça, yapı denetim şirketinin ilgili belediyeye karşı aynı zamanda imar mevzuatına göre fennî mesuliyeti de üstlenmiş olduğunu hüküm altına almıştır. Yapı Denetimi Hakkında Kanunda yapı denetim görevinin, İmar Kanununda ise fennî mesuliyet görevinin mevzuata uygun şekilde yerine getirilmemesi durumunda uygulanacak müeyyidelere ayrı ayrı yer verilmiştir. Buna göre, fennî mesuliyet görevi bakımından mevzuata aykırı hareketin İmar Kanununun 42'nci maddesi kapsamında, yapı denetimi görevi bakımından mevzuata aykırı hareketin ise Yapı Denetimi Hakkında Kanunun 8'inci maddesi kapsamında yaptırıma tabi tutulacağı tabiîdir.

20 Şubat 2020 tarihinden önce verilen ve kesinleşen cezalar bakımından uygulamanın Kabahatler Kanunu hükümleri çerçevesinde icra edilmesi gerekmektedir. Zîra Kabahatler Kanununun genel hükümleri, idarî para cezası veya mülkiyetin kamuya geçirilmesi yaptırımını gerektiren diğer kanunlar bakımından uygulanmak zorundadır (m.3). Bu manâda "aynı hareket" nedeniyle, örneğin projeye aykırı imâlatı tespit edip ilgili idareye bildirmeme hareketi nedeniyle, hem İmar Kanununa hem de Yapı Denetimi Hakkında Kanuna göre aynı firmaya ceza verilmesi durumunda, Kabahatler Kanununda düzenlenen "içtima" müessesesi kapsamında verilen cezanın çeşidine bakılarak bir değerlendirme yapılması uygun olacaktır. 20 Şubat 2020 tarihinden önce verilen ve kesinleşen cezalar yönünden, şayet her iki kanuna göre verilen ceza para cezası ve fiil sübuta ermiş ise, bu halde hangi ceza ağır ise bu ceza bakımından mahkemenin davanın reddine, hafif olan ceza bakımından cezanın iptaline karar vermesi yönteminin benimsenmesinin mevzuata uygun olacaktır. 20 Şubat 2020 tarihinden önce verilen ve kesinleşen cezalar yönünden her iki kanuna göre verilen cezalardan birisi para cezası iken diğeri para cezası haricindeki bir yaptırım ise, (fiil sübuta ermiş ise) her iki ceza bakımından da mahkemenin davanın reddine karar verilmelidir.

Öte yandan; 20 Şubat 2020 tarihinde Yapı Denetimi Hakkında Kanuna eklenen bir fikra ile, içtima müessesesine ilişkin olarak Kabahatler Kanununa göre özel nitelikli bir düzenlemenin yapıldı̆̆ görülmektedir. Bu nedenle 20 Şubat 2020 tarihinden sonra işlenen fiillere cezaların uygulanması ya da bu cezaların yargısal denetiminin yapılması esnasında, Yapı Denetimi Hakkında Kanunun 8'inci maddesine son fikra olarak eklenen fikranın göz önünde bulundurulmalıdır. Kezâ 20 Şubat 2020 tarihinden önce işlenmiş olan ve/veya İmar Kanununa göre ceza verilmiş olan fiillerin iptai talebiyle davalar açılmış ve bu davalar derdest ise, bu durumda mahkemelerin, Kabahatler Kanununun zaman bakımından uygulamaya ilişkin kuralları gereği, konuyu Yapı Denetimi Hakkında Kanunun 8'inci maddesine son fikra olarak eklenen hüküm bakımından da ele almasının gerekmektedir. Bu kapsamda yapılacak incelemede, 20 Şubat 2020 tarihinde yürürlüğe giren düzenlemeye göre, yapı denetim kuruluşuna sadece Yap1 Denetimi Hakkında Kanuna göre ceza verilebilmesi ve İmar Kanunu kapsamında ceza uygulanamaması için, yapı denetim kuruluşunun fiilinin her iki Kanunda da kabahat (idarî suç) olarak düzenlenmiş olması gerektiği; 
her iki kanun bakımından fiil aynı fiil değil ise, kezâ fiil her iki kanunda da aynı kabahat (idarî suç) olarak düzenlenmemiş ise, bu halde her iki Kanuna göre ayrı ayrı ceza uygulanmalıdır.

$\mathrm{Bu}$ itibarla; yukarıda arz ve izah edilen sebeplerle, yapı denetimi işini üstlenen firmanın aynı zamanda fennî mesuliyet görevini de üstlendiği, yapı denetimi görevi bakımından Yapı Denetimi Hakkında Kanuna fennî mesuliyet görevi bakımından İmar Kanununa tabi olduğu hususları göz önünde bulundurmaksızın; yargının şirket unvanında "yapı denetim şirketi” yazdığından bahisle, firmalara sadece Yap1 Denetimi Hakkında Kanuna göre ceza verilebileceği yönündeki yorumunun yeniden gözden geçirilmesi gerekmektedir.

\section{KAYNAKÇA}

AÇIKGÖZ, Ali Nevzat, Gerekçeli - Karşılaştırmalı - Açıklamalı Yeni Türk Ceza Kanunu, (Kendi Yayını), Van, 2005.

AKAT, Ali, "4708 Sayılı Yapı Denetimi Hakkında Kanun Ve İlgili Mevzuatında; Kontrol Elemanı İnşaat Mühendislerinin Görev Ve Sorumlulukları”, Yapı Denetimi Bilgilendirme Sunumu, TMMOB İnşaat Mühendisleri Odas1 İzmir Şubesi, İzmir, http://www.imo.org.tr/resimler/dosya_ekler/42beb6074c14528_ek.pdf?tipi $=2 \&$ turu $=X \&$ sube $=16, \quad$ erişim $\quad$ tarihi 18.06.2020.

AKBIYIKLI, Rıfat / OPÇIN, Gülhan / AKDEMIR, Merve / GÜNDÜZ, Emre, "Türkiye'de Yapı Denetim Kavramı, Amacı, Yasal Dayanağı ve Uygulamaları Üzerine Bir İnceleme”, Uluslararası Katılımlı 7. İnşaat Yönetimi Kongresi Bildiriler Kitabl, TMMOB İnşaat Mühendisleri Odası Samsun Şubesi Yayınları, Samsun, 2017.

ARTUKMAÇ, Sadık, Türk Imar Hukuku, Ayyıldız Matbaası, Ankara, 1969.

ASLAN, M. Yasin, "İdarî Yaptırımlar”, Türkiye Barolar Birliği Dergisi, Sayı 85, 2009.

ATABEY, İsmail İsa / BOZDOĞAN Kanat Burak, "Yapı Denetim Kanunu Uygulamalarında Sivas Örneği", 6. İnşaat Yönetimi Kongresi Bildiriler Kitabı, TMMOB İnşaat Mühendisleri Odası Yayınları, Bursa, 2011.

ATABEY, İsmail İsa / BOZDOĞAN, Kanat Burak, "Yapı Denetim Kanunu Uygulamalarında Sivas Örneği”, Engineering Sciences, Cilt 7, Sayı 1, Y11 2012.

BARDAKÇI, Mehmet Akif, Kabahatler Kanununa Göre İdarî Para Cezaları ve İdarî Para Cezalarının Yargısal Denetimi, İstanbul Üniversitesi Sosyal Bilimler Enstitüsü Yüksek Tezi, İstanbul, 2006.

BAYRAM, Savaş / AYDINLI, Serkan / BUDAK, Abdülkadir / ORAL, Emel, "Türkiye'de Yapı Üretiminde Ve Denetiminde Yaşanan Etik Sorunlar”, Pamukkale Üniversitesi Mühendislik Bilimleri Dergisi, Cilt 24, Sayı 3, Yıl 2018.

BEKÂR, Elif, “Kabahatler Kanunu'nun Genel Hükümlerinin Değerlendirilmesi”, İstanbul Üniversitesi Hukuk Fakültesi Mecmuası, Cilt 69, Sayı 1-2.

BİLGIN, Hüseyin, "7221 sayılı Kanunla 3194 sayılı Kanunda Yapılan Değişiklikler Hakkında Bir İnceleme”, Mahallî İdareler Dergisi, Mayıs-Haziran 2020, Sayı 89-90.

CEBECİ, Şeyma, Türk Ceza Hukuku Bağlamında Ne Bis In Idem Illkesi, İstanbul Bilgi Üniversitesi Yüksek Lisans Tezi, İstanbul, 2018.

ÇELIK, Mehmet, "Yapı Denetim Mevzuatı Ve Uygulamada Karşılaşılan Sorunlar - Tartışmalar Kısmı”, V. Ulusal Tesisat Mühendisliği Kongresi Ve Sergisi Paneller Kitabı, TMMOB Makine Mühendisler Odası Yayınları, İzmir, 2001.

DAVRAZ, Metin / BAȘPINAR, Ebru, CEYLAN, Hakan, "Yapı Denetim Kurumları Öncesi Isparta ve Yakın Civarındaki Hazır Beton Kalitesi”, Teknik Bilimler Dergisi, Y11 2012, Cilt 2, Sayı 1.

DEMİRCIOĞLU, Huriye Reyhan, "Sorumluluk Hukukunun İkili Yapısının Aşılması Çabalarının Ürünleri Olarak Culpa In Contrahendo Ve Güven Sorumlulukları", Sorumluk ve Tazminat Hukuku Sempozyumu, Gazi Üniversitesi Hukuk Fakültesi Yayınları, Ankara, 2009.

DEVELLİOĞLU, Ferit, Osmanlıca-Türkçe Ansiklopedik Lûgat, Aydın Kitabevi Yayınları, Ankara, 2007. 
DİLKEN, Uğur, “İmar Kanunun 42’nci Maddesi Uyarınca 2020 Yılında Uygulanacak İdarî Para Cezaları”, Mahallî İdareler Dergisi, Say1 85, Ocak 2020.

DINÇ Güney, "Depremler, Mimar - Mühendisler ve Hukuk", http://www.guneydinc.com/makaleler/122.pdf, erişim tarihi 11.01.2020.

DUMAN, Barış, "4708 Sayılı Kanun Çerçevesinde Yapı Denetim Kuruluşunun İş Sağlığı ve Güvenliği Sorumluluğu”, Türkiye Barolar Birliği Dergisi, Yıl 2019, Sayı 143.

EKINCİ, Murat, "Ceza Hukuku Açısından İdarî Yaptırımlar", Yıldırım Beyazıt Hukuk Dergisi, Yı1 2017, Sayı

3.

ERDINÇ, Burcu, "İdarî Yaptırımların Kavramsal Çerçevesi ve Cezaî Yaptırımlarla Karşılaştırılması”, Ankara Barosu Dergisi, Y11 2012, Say1 2.

ESIN, Yüksel, İdarenin Hukukî Sorumluluğu, Balkanoğlu Matbaacılık, Ankara, 1973.

Gişı̇, Selçuk, "Kabahatleri Suç Olmaktan Çıkarma Eğilimi Ve Kabahatler Kanunu”, İnönü Üniversitesi Hukuk Fakültesi Dergisi, Cilt 8, Sayı 1, Y11 2017.

GÖLCÜKLÜ, Feyyaz, "İdarî Ceza Müeyyideleri ve Bunlara Karşı Kanun Yolları”, Ankara Üniversitesi Siyasal Bilgiler Fakültesi Dergisi, C. 18, Sayı 3-4, Y11 1963.

GÖZLER, Kemal, İdare Hukuku - Cilt I, Ekin kitabevi Yayınları, Bursa, 2009.

GÖZLER, Kemal, Mahallî İdareler Hukuku, Ekin Kitabevi Yayınları, Bursa, 2018.

KANAR, Mehmet, Osmanlı Türkçesi Sözlüğü, Say Yayınları, İstanbul, 2009.

KART, Aslıhan / KETIZZMEN, Muammer, "Kabahatler Kanunu'nun İçtima Hükümleri Açısından Kişisel Verilerin Korunmasına İlişsin Suç ve Kabahatler ile Kurul'un İdarî Ceza Kararlarına İlişskin Bir Değerlendirme", Kişisel Verileri Koruma Dergisi, Cilt 1, Sayı 2, Y11 2019.

KIRANER, Cihan, "Yap1 Denetimi Kuruluşları ve Türkiye'de Yap1 Denetimi Uygulamaları", http://www.leventbicakci.com/cihan.pdf, erişim tarihi 18.06.2020.

KURAL, Recep / ÜNAL, Osman, "İnşaat Sektöründe Yap1 Denetimi ve Afyonkarahisar İlindeki Uygulamaların Araştııılması", Afyon Kocatepe Üniversitesi Fen ve Mühendislik Bilimleri Dergisi, Y11 2015, Say1 15.

KURT, Hayrettin, "İdarî Yaptırımlara Karşı Güvenceler”, Gazi Üniversitesi Hukuk Fakültesi Dergisi, C. 18, Y11 2014.

MEYDANLI ATALAY, Hilâl / ENGİN, Serkan, "Yapı Denetiminin İstihdama Katkı1s", TMMOB İnşaat Mühendisleri Odası 3. Yapı Denetimi Sempozyumu Kitabı, İnșaat Mühendisleri Odası Yayınları, Ankara, 2013.

OĞURLU, Yücel, İdarî Yaptırımlar Karşısında Yargısal Korunma, Seçkin Yayınevi, Ankara, 2001.

OKAY TEKINSOY, Özge, “Kolluk”, İdare Hukuku, YILDIRIM, Turan / YASIN, Melikşah / KAMAN, Nur / ÖZDEMIR, H. Eyüp / ÜSTÜN, Gül / OKAY TEKINSOY, Özge, XII Levha Yayınları, İstanbul, 2013.

ÖMÜRBEK, Nuri / KARAATLI, Meltem / CÖMERT Hafize Gonca, “Ahp-Saw Ve Ahp-Electre Yöntemleri ile Yapı Denetim Firmalarının Değerlendirmesi”, Yönetim Bilimleri Dergisi, Cilt 14, Sayı 27, Y11 2016.

ÖZDEMIR, Selman, "İmar Para Cezaları Özelinde İdarî Yaptırımların Zaman Bakımından Uygulanması", Türk İdare Dergisi, Say1 473, Aralık 2011.

ÖZDEMİ, Selman, "Yapı Ruhsatının Kolluk/Zabıta Niteliği”, Mahallî İdareler Dergisi, Sayı 51, Mart 2017.

ÖZDEMIR, Selman, İmar - İdare Hukukunda Kazanılmış Hak, Adalet Yayınları, Ankara, 2019.

ÖZEN, Mustafa, "Non Bis İn İdem (Aynı Fiilden Dolayı İki Kez Yargılama Olmaz) İlkesi”, Gazi Üniversitesi Hukuk Fakültesi Dergisi, C. 14, Y11 2010.

ÖZEN, Mustafa, "İş Kazalarında Hukuki, Cezai ve İdari Sorumluluk”, Ankara Barosu Dergisi, Y11 2015, Sayı

2.

PALA Murat / DEMIR, Mehmet Şirin, "Güneydoğu Anadolu Bölgesinde Yapı Denetimi Uygulamasında Karşılaşılan Sorunlar Ve Bu Sorunlara İlişkin Çözüm Önerileri”, Adlyaman Üniversitesi Mühendislik Bilimleri Dergisi, Y11 2017, Say1 6.

REISOĞLU, Safa, Borçlar Hukuku - Genel Hükümler, Beta Yayınları, İstanbul, 2004.

SÜRBEHAN, Sadrettin, "İdarî Müeyyide Ve İdarî Ceza Hukuku”, Türk İdare Dergisi, Y11 1971, Sayı 328.

TBMM, Başbakanlık Kanunlar ve Kararlar Genel Müdürlüğü'nün 22.01.2001 Tarih ve 3065 Sayılı Yazısı Eki

"Yap1 Denetimi Hakkında Kanun Tasarısı ve Tasarı Gerekçesi”, https://www.tbmm.gov.tr/tutanaklar/TUTANAK/TBMM/d21/c068/tbmm21068128ss0732.pdf, $\quad$ erişim tarihi 10.01.2020. 
TBMM, İstanbul Milletvekili Mustafa Demir ile 70 Milletvekilinin Coğrafi Bilgi Sistemleri ile Bazı Kanunlarda Değişiklik Yapılması Hakkında Kanun Teklifi (2/2512) ve Bayındırlık, İmar, Ulaştırma ve Turizm Komisyonu Raporu, https://www.tbmm.gov.tr/sirasayi/donem27/yil01/ss161.pdf, erişim tarihi 22.05.2020.

TOROSLU, Nevzat, Cürümlerin Tasnifi Bakımından Suçun Hukukî Konusu, Ankara Üniversitesi Hukuk Fakültesi Yayınları, Ankara, 1970.

TOROSLU, Nevzat, Ceza Hukuku, Savaş Yayınevi, Ankara, 2005.

TULAY, Muhammed Emre, "Kanunilik İlkesi Işı̆̆ında Ceza Hukuku Kurallarının Zaman Bakımından Uygulanması Ve Delil Elde Etme Yöntemlerinde Zaman Bakımından Uygulanma Sorunu”, Marmara Üniversitesi Hukuk Fakültesi Hukuk Araştırmaları Dergisi - Cevdet Yavuz’a Armăgan, Cilt 22, Sayı 3, Y1l 2016.

Türk Dil Kurumu, "Fennî”, https://sozluk.gov.tr/, erişim tarihi 13.02.2020.

YURTCAN, Erdener, Yargıtay Kararları Işı̆̆ında Kabahatler Kanunu ve Yorumu, Türkiye Barolar Birliği Yayınları, Ankara, 2016.

Anayasa Mahkemesi Kararlar1; www.anayasa.gov.tr

Danıştay, Bölge İdare Mahkemesi, İdare Mahkemesi Kararları; UYAP Bilişim Sistemi.

Mevzuatlar; www.resmigazete.gov.tr / www.mevzuat.gov.tr 